\title{
The geographical psychology of recent graduates in the Netherlands: Relating environmental factors and personality traits to location choice
}

Citation for published version (APA):

Hooijen, I., Bijlsma, I., Cörvers, F., \& Poulissen, D. (2020). The geographical psychology of recent graduates in the Netherlands: Relating environmental factors and personality traits to location choice. ROA. ROA Research Memoranda No. 001 https://doi.org/10.26481/umaror.2020001

Document status and date:

Published: $13 / 02 / 2020$

DOI:

10.26481/umaror.2020001

Document Version:

Publisher's PDF, also known as Version of record

Please check the document version of this publication:

- A submitted manuscript is the version of the article upon submission and before peer-review. There can be important differences between the submitted version and the official published version of record.

People interested in the research are advised to contact the author for the final version of the publication, or visit the DOI to the publisher's website.

- The final author version and the galley proof are versions of the publication after peer review.

- The final published version features the final layout of the paper including the volume, issue and page numbers.

Link to publication

\footnotetext{
General rights rights.

- You may freely distribute the URL identifying the publication in the public portal. please follow below link for the End User Agreement:

www.umlib.nl/taverne-license

Take down policy

If you believe that this document breaches copyright please contact us at:

repository@maastrichtuniversity.nl

providing details and we will investigate your claim.
}

Copyright and moral rights for the publications made accessible in the public portal are retained by the authors and/or other copyright owners and it is a condition of accessing publications that users recognise and abide by the legal requirements associated with these

- Users may download and print one copy of any publication from the public portal for the purpose of private study or research.

- You may not further distribute the material or use it for any profit-making activity or commercial gain

If the publication is distributed under the terms of Article $25 \mathrm{fa}$ of the Dutch Copyright Act, indicated by the "Taverne" license above, 


\section{Maastricht University $\quad$ ROA}

The geographical psychology of recent graduates in the Netherlands: Relating environmental factors and personality traits to location choice

Inge Hooijen Ineke Bijlsma Frank Cörvers

Davey Poulissen

\section{ROA Research Memorandum}

ROA-RM-2020/1

Researchcentrum voor Onderwijs en Arbeidsmarkt | ROA Research Centre for Education and the Labour Market / ROA 


\title{
The geographical psychology of recent graduates in the Netherlands: Relating environmental factors and personality traits to location choice
}

\author{
Inge Hooijen \\ Ineke Bijlsma \\ Frank Cörvers \\ Davey Poulissen \\ ROA-RM-2020/1 \\ February 2020
}

Research Centre for Education and the Labour Market Maastricht University

P.O. Box 616, 6200 MD Maastricht, The Netherlands

$\mathrm{T}+31433883647 \mathrm{~F}+31433884914$

secretary-roa-sbe@maastrichtuniversity.nl www.roa.nl 


\section{Abstract \\ The geographical psychology of recent graduates in the Netherlands: Relating environmental factors and personality traits to location choice*}

There is ample evidence from different research disciplines that location factors such as employment opportunities or the availability of amenities and facilities are a powerful predictor of settlement behaviour. Recent research suggests that citizens' mean personality traits could be an additional predictor of where young people settle. We therefore explore 1) the extent to which recent graduates in the Netherlands are geographically clustered with respect to five different personality traits, 2) whether the geographical clustering of graduates is intensified as they grow older, 3) how regional environmental characteristics are related to personality traits, and 4) the extent to which personality traits play a role in graduates' location choices. Our results reveal a distinct geographical clustering of personality traits among the different regions in the Netherlands. We also show that this geographical clustering becomes more blurred as graduates age. The results furthermore show robust associations between personality traits and several environmental characteristics with respect to demographic, economic, health, political, sociocultural, crime, and religious outcomes. In addition, we show that personality traits play a role in graduates' location choices. Economic factors seem to have a larger impact in determining location choices than personality traits.

JEL classification: J61, R23, D91

Keywords: personality traits, geographical psychology, recent graduates, settlement behaviour

Inge Hooijen

Maastricht University

ROA

P.O. Box 616

NL-6200 MD Maastricht

The Netherlands

i.hooijen@maastrichtuniversity.nl

and NEIMED

Frank Cörvers

Maastricht University

ROA

P.O. Box 616

NL-6200 MD Maastricht

The Netherlands

frank.corvers@maastrichtuniversity.nl

Tilburg Law School/Tilburg University

and CAOP
Ineke Bijlsma

Maastricht University

ROA

P.O. Box 616

NL-6200 MD Maastricht

The Netherlands

i.bijlsma@maastrichtuniversity.nl

Davey Poulissen

Maastricht University

ROA

P.O. Box 616

NL-6200 MD Maastricht

The Netherlands

d.poulissen@maastrichtuniversity.nl

* We are grateful for the feedback and suggestions of Arthur Grimes during the special session on location choice and the impacts of interregional migration at the 2018 ERSA conference in Cork, Ireland. We also thank the participants of that session, as well as the participants of the Migration Conference in Lisbon in 2018, the Belgian Day for Labour Economists in Maastricht in 2019, and the seminar organized by the Institute for Employment Research in Nuremberg in 2019. We are furthermore grateful for the feedback and suggestions of Merve Özer and Christoph Meng. We would also like to thank Jim Allen and Jessie Bakens for their suggestions on earlier versions. 


\section{Introduction}

Recent graduates are often regarded as the ideal individual to attract and retain, since they are considered an asset to regional economies for their contribution to economic performance and development (Czaika, 2018). The determinants of graduates' settlement behaviour have therefore gained increasing research attention during the last decades (Abreu, Faggian, \& McCann, 2014; Venhorst, Van Dijk, \& Van Wissen, 2010; Faggian, McCann, \& Sheppard, 2007a). A substantial strand of literature focuses on human capital migration models (Greenwood, 1985; Sjaastad, 1962) in understanding the settlement behaviour of recent graduates (Venhorst \& Cörvers, 2018; Lammarino \& Marinelli, 2015). A common conclusion of such models is that economic determinants play a significant role in the settlement behaviour of recent graduates. Other scholars have examined the role of how long one has been living in a study region (Teichert, Niebuhr, Otto, \& Rossen, 2018; Andrews, Clark \& Whittaker, 2011) and the role of non-economic determinants - such as social ties, the quality of life, amenities, regional familiarity (Hooijen, Meng, Reinold, \& Siegel, 2017; Imeraj, Willaert, Finney, \& Gadeyne, 2017; Venhorst, 2012) - and find these determinants to be important in understanding location choice. These approaches have received relatively sparse attention compared to economic factors in explaining the settlement behaviour of recent graduates. Even less weight is given to the role of psychological factors as drivers of internal mobility. ${ }^{1}$ We propose personality traits as a potential explanatory factor in the location choices of recent graduates. Studies show that psychological factors are an essential factor in decision making processes in different life domains (Becker et al., 2012). To our knowledge, there has been no research on the role of personality traits in conjunction with the location choices of people within the country in which they have recently graduated. ${ }^{2}$ Our underlying thought is that differences in the psychological make-up of people are an important factor contributing to heterogeneity in settlement behaviour.

The psychological literature does provide some first insights on the role of personality traits in migration studies. Research has focused on the role of personality traits in relation to the probability of intending to emigrate (Canache, Hayes, Mondak, \& Wals, 2013; Jokela, 2009) and finds that high

1. Unless otherwise formulated in the studies we refer to, we use the concept of mobility instead of migration to define the movement, that is, residence change, of recent graduates between municipalities in the Netherlands. Mobility is a broader concept that covers different movements, including various forms of migration, whereas migration is often defined as long-distance and long-term moves of at least one year (Aybek, Huinink, \& Muttarak, 2015; King \& Raghuram, 2013; King \& Findley, 2012). Accordingly, although migration is one form of mobility, not all forms of mobility can be considered to be migration (e.g. commuting, business trips).

2. Fouarge et al. (2019) use a sample of German students to study the probability of having the intention of emigrating and the likelihood of choosing a culturally remote location for different personality traits. 
scorers on extraversion and openness to experience and low scorers on agreeableness have a higher probability of have the intention of being spatially mobile (Jokela, 2014). Studies not only reveal that specific personality traits have an impact on mobility intentions, but also find robust evidence that particular personality traits are more prevalent in some regions than in others. Furthermore, these studies find significant relationships between personality traits and regional indicators regarding, for example, economic and political outcomes (Rentfrow, Jokela \& Lamb, 2015; Rentfrow et al., 2013). ${ }^{3}$ This could be a result of individuals seeking environments that best fit their personality (Motyl et al., 2014; Rentfrow, Gosling, \& Potter, 2008). Therefore, personality could not only influence the intention of being spatially mobile, but also impact the settlement location. Following the psychological literature and inspired by the work of Rentfrow and colleagues $(2015,2014)$, we hypothesize that individuals sort themselves out to regions that suit their psychological traits. Even though economic and social returns matter in settlement behaviour, if people settle down in places that also fit their personalities, this suggests that strategies to attract certain types of people to environments should go beyond economic and social forces and additionally focus on the alignment between psychological traits and environmental characteristics.

The starting point of this study is an analysis of self-reported personality traits covering the Big Five personality traits - agreeableness $(A)$, conscientiousness $(C)$, extraversion $(E)$, neuroticism $(N)$, and openness to experience (O) - at the local level. This paper addresses four main questions. First, to what extent are personality traits among recent graduates geographically clustered in the Netherlands? Second, how does the clustering of the personality traits of young people develop over time? Third, how are environmental characteristics - such as demographic, social, physical, and economic factors - correlated with personality traits? Last, to what extent do personality traits play a role in location choice?

This study focuses on the personality traits of recent graduates of universities of applied sciences in the Netherlands. As new job seekers, recent graduates are geographically more mobile than the average population, which could result in a more intense geographical sorting of these graduates relative to other periods in their life course (Venhorst, Van Dijk, \& Van Wissen, 2011; Fielding, 1992). The geographical clustering of the personality traits of recent graduates can also become more concentrated through job place sorting. Hence, individuals with similar inclinations sort themselves

3. The spatial distribution of psychological phenomena and the interaction of citizens' mean personality traits with regional characteristics is studied by the emerging field of geographical psychology (Rentfrow \& Jokela, 2016). In this paper, personality traits refer to the individual level, and personality profiles to an aggregated geographical level. 
out to certain areas that could reflect certain personality traits more strongly than others (e.g. Silicon Valley) (Garretsen et al., 2019; Rentfrow, 2010).

We explore the geographical distribution of personality traits based on the residential location of recent graduates of universities of applied sciences 1.5 years after graduation and four to eight years after graduation. We can thus examine whether the geographical clustering changes throughout time. Our research approach is new in several ways. First, it focuses on a specific subgroup during two moments in their life course rather than analysing geographical differences in the mean personality traits of heterogeneous groups at one moment in time, as has been done so far. Second, it analyses a multidisciplinary set of environmental factors that could be correlated to personality traits, therefore contributing to a broader understanding of graduates' settlement patterns. Third, it presents additional explanations to understand the settlement behaviour of recent graduates of universities of applied sciences in the Netherlands. In particular, we add to the literature on graduate mobility an exploration of the role of personality traits in settlement behaviour by applying a discrete choice model.

The results illustrate the geographical clustering of personality traits across Dutch regions and that this clustering weakens over time for recent graduates of universities of applied sciences. In addition, our results indicate a relationship between specific personality traits and the residential environment. For example, openness to experience and conscientiousness are, respectively, positively and negatively correlated with indicators of urbanity. Lastly, the results of the discrete choice model suggest that economic indicators have the largest impact on location choice. Personality does affect the perceived attractiveness of environmental factors and therefore influences location choice, too. Modelling the interplay between several environmental factors - such as economic and demographic composition, physical green space, crime levels, and the political environment and their interaction with personality - contributes to the understanding of location choice.

The paper is structured as follows. Section 2 provides an overview of empirical findings on the settlement behaviour of recent graduates of universities of applied sciences and previous findings on the relationship between different environmental factors and personality traits. Section 3 describes the dataset and the main variables of interest. Section 4 explains the methodology. Sections 5 and 6 outline and discuss the results, respectively. Section 7 concludes the paper, and Section 8 discusses ideas for future research. 


\section{Settlement behaviour, graduates, and personality traits}

The places in which people live differ considerably with respect to their cultural, social, and institutional contexts, their physical appearance, and demographic and economic composition. Places consist of communities shaped by people, in which large groups of local people actively participate, and in which individuals with particular psychological traits can be overrepresented. The psychological traits of groups of individuals can therefore influence or even form a place and contribute to its particular regional character. Over the last decade, research in geographical psychology has revealed profound differences between the Big Five personality traits within metropolitan London (Jokela et al., 2015), across regions in Great Britain (Rentfrow et al., 2015), across different US states (Rentfrow et al., 2013; Rentfrow, 2010), and between administrative regions of the Russian Federation (Allik et al., 2009). Furthermore, it has identified robust associations between the personality profiles of locations and regional indicators such as urban economic growth (Garretsen et al., 2019), the number of entrepreneurial activity (Stuetzer et al., 2018; Obschonka et al., 2013), innovation rates (Lee, 2017), and the level of social capital and political orientation (Rentfrow et al., 2013).

\subsection{Settlement behaviour among recent graduates}

A common observation is that environments with a high stock of human capital foster innovation and economic productivity, provide higher wages, and hence attract new, highly educated labour market entrants. Higher education institutions are thereby increasingly recognized as key regional players, since they provide regions with a substantial part of needed human capital. Regional economic development is closely tied to knowledge exchange and creation, with recent graduates with the upto-date knowledge acquired during their studies playing an important role in the knowledge transfer within and across regions (Corcoran \& Faggian, 2017; Abreu, Koster \& Venhorst, 2014; Faggian \& McCann, 2009a; Glaeser, Kolko, \& Saiz, 2001).

Research on highly educated graduates' settlement behaviour indicates that economic considerations are often a key element in location choice. Prior research in Italy (Marinelli, 2013) and in England and Wales (Faggian \& McCann, 2009b) finds that spatial mobility among recent graduates is particularly directed towards innovative regions. Berck, Tano, and Westerlund (2016) find that, in Sweden, regions with a higher per capita tax base are especially favoured by young adults. Haussen and Uebelmesser (2015) and Krabel and Flöther (2014) also find that the flows of graduates towards German regions depends positively on these regions' favourable economic conditions and high shares of human capital. Carree and Kronenberg (2014) and Venhorst et al. (2011) find that graduates tend to be attracted to Dutch regions that offer ample job opportunities and a low cost of living. Studies in Sweden (Ahlin, Andersson, \& Thulin, 2014), Germany (Krabel \& Flöther, 2014), Finland (Haapanen \& 
Tervo, 2012), and the Netherlands (Venhorst, 2012) furthermore find that individuals often leave rural or peripheral regions to settle down in (large) urban areas after graduation. Moreover, recent graduates are, on average, more mobile compared to individuals at other stages in the life course (Corcoran \& Faggian, 2017). In addition, prior spatial mobility increases the likelihood of future mobility (Krabel \& Flöther, 2014; Haapanen \& Tervo, 2012).

A common conclusion of these studies is that recent graduates are highly mobile and move towards economically prosperous places. However, the extent to which spatial mobility itself actually leads to a positive return on the graduates' human capital investment remains unclear. For the Netherlands, Venhorst and Cörvers (2018) show that the positive and significant effects of greater internal graduate mobility on hourly wage rates and good job matches mostly disappear after controlling for selfselection. The authors point to unobservable personal traits such as ambition or motivation as underlying factors in obtaining positive returns on internal migration. Moreover, studies by Teichert et al. (2018), Hooijen et al. (2017) and Imeraj et al. (2017) point to components other than economic factors, such as how long one has been living in an area, the importance of familiarity with the region, the quality of life, and social networks underlying spatial mobility, or the intention to be spatially mobile. In addition, Fouarge et al. (2019) study the intention to emigrate after graduation, using a German sample that takes into account the role of personality traits. They find that students scoring high on openness to experience and extraversion are more likely to have the intention to emigrate after graduation, in contrast to more conscientious and agreeable students. The authors furthermore find that the role of the cultural context and the language spoken in the host country is differently associated with location choice according to personality traits. This topic is discussed in the following section.

\subsection{Environmental characteristics and their relationship with personality traits}

The literature on the Big Five personality traits has shown that personality traits are related to environmental characteristics. In this section, we review the findings by personality trait.

High scorers on agreeableness tend to be clustered in areas with more elderly people and more children and tend to be more satisfied living in spacious areas and in family-occupied households (Jokela et al., 2015). Agreeableness is negatively related to entrepreneurial activity and employment growth (Stuetzer et al., 2018; Obschonka et al., 2013). Agreeable individuals tend to be clustered in areas with more green space (Jokela et al., 2015). This trait is negatively related to votes for conservative candidates in general elections (Rentfrow et al., 2015). Furthermore, Rentfrow et al. (2008) find agreeable individuals to be negatively related with higher mortality rates and fewer deaths 
due to cancer and heart disease. In addition, agreeable individuals are shown to have strong ties with the communities they live in (social capital) and exhibit prosocial behaviour (social norms) (Rentfrow, 2014; Rentfrow, 2010; Rentfrow et al., 2008). Agreeableness is negatively related to rates of robbery, murder, and property crime and positively related to religiosity (Rentfrow et al., 2008). This result is in line with the features of agreeableness, since they convey friendly, trusting, and kind personalities (Ashton, 2007). Lastly, high scorers on agreeableness tend to be less geographically mobile (Fouarge et al., 2019; Rentfrow \& Jokela, 2016; Jokela, 2009).

For conscientiousness, Rentfrow et al. (2015) find a positive association with the proportion of married residents. Obschonka et al. (2013) find conscientiousness to be positively related to state-level entrepreneurial activity, and Stuetzer et al. (2018) find it to be positively related to stronger regional employment growth. Lee (2017) finds this trait to be positively related to innovation (patenting) in England and Wales. The positive associations with economic indicators reflect this trait's characteristics, such as being organized, efficient, self-disciplined, and compliant (Ashton, 2007). Conscientiousness is positively related to votes for conservative candidates in general elections in England and negatively related to votes for labour parties (Rentfrow et al., 2015). Conscientiousness also seems to have a positive association with regional health (e.g. is positively related to life expectancy and negatively related to age-standardized mortality rates). Rentfrow et al. (2008) find the trait to have a positive relation with health-promoting behaviour in US states, and Rentfrow et al. (2015) find it to have a positive association with life expectancy and a negative relationship with longterm health problems, stroke, cancer, and heart disease mortality in British districts. In addition, Rentfrow et al. (2008) find conscientiousness to be negatively related to indicators of social involvement, and Rentfrow (2010) finds social capital to be negatively related to state-level conscientiousness. The reasoning behind this outcome is not discussed, however. Indicators reflecting social factors are usually linked to the personality traits of extraversion and agreeableness. Lastly, Ayhan, Gatskova, and Lehmann (2017) find a negative association between conscientiousness and the likelihood of moving from a rural to an urban area, using panel data from the Ukrainian Longitudinal Monitoring Survey.

High scorers on extraversion tend to be energetic, talkative, and optimistic and enjoy social interactions (Ashton, 2007). Rentfrow et al. (2015) find profound and high levels of extraversion mainly in London and its surrounding districts. Jokela, Elovainio, Kivimäki, and Keltikangas-Järvinen (2008) find that highly sociable Finnish individuals aged 15 to 30 are significantly more likely to settle down in urban areas. Oishi, Talhelm, and Lee (2015) find that, in the United States, extraverts prefer 
oceans over mountains and introverts prefer living in mountainous regions. As with demographic density, extraversion is shown to be positively related to economic viability. Extraversion has a positive association with state-level entrepreneurial activity (Obschonka et al., 2013) and greater regional employment growth (Stuetzer et al., 2018). Rentfrow et al. (2015) find this trait to be positively related to high levels of education and income and high-status occupations. They furthermore find extraversion to be negatively related to votes for labour parties. Rentfrow et al. (2008) find a negative association with health-promoting behaviour. However, Rentfrow et al. (2015) find extraversion to be positively related to a long life expectancy and negatively related to long-term health problems, cancer, and heart disease mortality. Extraverts tend to have greater social networks, to interact and share ideas more often, and to build networks that positively relate to the sociocultural composition of the environment. Extraverts are more likely to live in a vibrant and culturally diverse urban environment (Jokela, 2014, 2009) and are more socially involved (Rentfrow et al., 2008). Rentfrow (2010) finds social capital to be positively related to state-level extraversion, and Rentfrow et al. (2015) find a positive association with social diversity (foreign-born residents). Murray et al. (2005) find that, in Australia, mean levels of extraversion are significantly higher in areas with greater accessibility to amenities and opportunities for social interaction. In addition, extraversion is positively related to robbery and murder rates and positively related to religiosity in US states (Rentfrow et al., 2008). Lastly, for German students who intend to emigrate, extraversion has a negative correlation with having the intention to move to a more culturally remote country. Moreover, these students are more likely to move to countries where either German or English is the official language (Fouarge et al., 2019).

Individuals scoring high on neuroticism are considered to be somewhat moody, sensitive, and unstable (Ashton, 2007). Note that these features do not indicate any psychological disorder and that the individual differences with respect to these traits within regions are usually larger than the regional differences between individuals' mean scores (Costa \& McCrae, 2008; Allik \& McCrae, 2004). Garretsen et al. (2019), Stuetzer et al. (2018), Rentfrow et al. (2015), and Obschonka et al. (2013) find this trait to be more prevalent in areas that are less economically vibrant and in areas with lower levels of entrepreneurship. Rentfrow et al. (2015) find neuroticism to be positively related to votes for labour parties and negatively related to votes for liberal democrats. Furthermore, neuroticism is shown to be negatively related to health-promoting behaviour and life expectancy and positively related to longterm health problems and deaths due to heart disease and cancer (Rentfrow et al., 2015; Rentfrow et al., 2008). In addition, this trait is negatively related to social capital and several indictors of social involvement (Rentfrow, 2010; Rentfrow et al., 2008). Lastly, neuroticism is negatively associated with robbery rates. 
Individuals who score high on openness to experience are characterized by creativity, curiosity, imagination, and intellect (Ashton, 2007). In Great Britain, Rentfrow et al. (2015) find high scorers on openness to experience to be more prevalent in urban areas such as London, Oxford, and Bristol. Additionally, the wealthier regions of the Russian Federation, such as Moscow and St. Petersburg, have high mean scores of openness to experience, in contrast to the least developed regions, such as Kurgan and Buryatia (Allik et al., 2009). Research furthermore shows that urban areas especially attract individuals scoring high on openness to experience and that high scorers on openness to experience are more satisfied living in densely populated areas and more culturally diverse areas (Jokela et al., 2015). Furthermore, the probability of rural-to-urban migration is more likely for high scorers on openness to experience in Ukraine (Ayhan et al., 2017). Rentfrow et al. (2015) find this trait to be negatively related to the proportion of married residents. Allik et al. (2009) and Rentfrow et al. (2008) find a positive association between openness to experience and regional human capital and economic prosperity. Furthermore, just as extraversion and conscientiousness, this trait is positively related to an entrepreneurship-prone personality profile and hence greater regional employment growth (Stuetzer et al., 2018) and state-level entrepreneurial activity (Obschonka et al., 2013). With regard to political behaviour, studies find openness to experience to be positively related to a liberal public opinion (Rentfrow et al., 2008), left-leaning US states (Rentfrow, 2010), and votes for liberal democrats (Rentfrow et al., 2015). With respect to health, Rentfrow et al. (2015) find this trait to be positively related to life expectancy and negatively related to cancer mortality. This study furthermore finds a positive association with same-sex couples and foreign-born residents in British districts. Lastly, and unlike for extraversion, Fouarge et al. (2019) find openness to experience among German students to be positively related to willingness to emigrate to more culturally remote countries. Together with neuroticism, openness to experience exhibits the most obvious geographical clustering among the Big Five personality traits in different empirical studies (Rentfrow \& Jokela, 2016).

\subsection{How do geographical differences in personality traits emerge?}

The literature distinguishes several plausible factors in explaining why similarities in personality traits are so apparent among individuals living in close geographical proximity. Genetic and cultural influences, the physical environment, and selective migration are the main factors that tend to contribute to the origin of similar personality traits among people in close geographical proximity.

The first factor refers to the heritability of personality traits (Allik \& McCrae, 2004). Several studies find that personality traits have substantial heritable components (Vukasović \& Bratko, 2015; Bouchard \& Loehlin, 2001). For example, Vukasović and Bratko (2015) show that about 40 per cent of the variance in personality traits can be accounted for by genetic influences and the remainder can be 
explained by environmental influences. A second argument reflects the extent to which culture ${ }^{4}$ (institutions) and its facets (e.g. values, beliefs, habits, language, and religion) interact with personality traits and thereby shape the behaviours of individuals and groups (Hofstede \& McCrae, 2004). Allik and McCrae (2004) and Hofstede and McCrae (2004) find positive associations between mean personality scores and culture dimension scores and geographically proximate cultures. These authors suggest that personality traits can be related to different cultural characteristics. Similar thoughts are discussed by Rentfrow et al. (2008), who refer to this as social influence. A third factor refers to the physical environment. Characteristics such as climate, green space, and densely populated areas can affect the prevalence of certain personality traits. For example, Schaller and Murray (2008) find low scores on extraversion and openness in regions with a greater prevalence of infectious diseases. To limit pathogen transmission, the people themselves avoided disease by being more cautious and having fewer social interactions.

The above arguments not only are separate reflections of the origins of personality traits, but also usually consider mutually reinforcing or intertwined factors. They furthermore do not outline any causal ordering. The arguments all assume that geographical proximity bonds individuals and the communities or networks in which they interact. In social environments with different networks and communities, individuals can influence each other and reinforce behaviours by shared genes, norms, and beliefs. These assets can continuously shape and reinforce the local prevailing personality profile (Rentfrow et al., 2013).

The last argument, which is the main focus of this study, refers to selective migration. The underlying assumption is that people sort themselves into places that provide a lifestyle aligned with their own personality traits and resulting needs (Rentfrow \& Jokela, 2016; Rentfrow et al., 2008; Hofstede \& McCrae, 2004). For example, high scorers on extraversion and openness to experience are more likely to settle down in economically vibrant and culturally diverse urban environments (Rentfrow \& Jokela, 2016). In addition, Motyl et al. (2014) find that a weaker sense of belonging to a geographical area, explained by a lack of fit between personal and community ideological values, increases the likelihood of leaving a community.

The four arguments above indicate that people with similar personality traits are inclined to live close to each other in the same areas or seek to move to areas with environmental characteristics that best

4. We refer to culture as 'the collective programming of the mind that distinguishes one group or category of people from another', as defined by Hofstede and McCrae (2004, p. 58). 
fit their personalities (fourth argument). We refer to this as personality sorting. In addition, the distribution of personality profiles across regions can also arise through job place sorting over a longer period of time, which can, for example, result into enclaves for the creative class (e.g. Silicon Valley). Individuals with similar inclinations thus sort themselves out to certain areas that can reflect some personality traits more strongly than others (Rentfrow, 2010). Furthermore, the sorting of different personalities into specific areas can reflect heterogeneous preferences and thus influence the provision of amenities and local public goods. The missing chapter in geographical psychology is, however, whether regional personality differences do indeed arise from selective internal migration (Rentfrow et al., 2015; Park \& Peterson, 2014).

It is important to stress that the relationship between personality traits and the environment can go in two directions: either personality traits affect the environment, or the environment influences the psychological characteristics of individuals. With regard to the latter, individuals would then adapt their personality to fit into their new environment. However, since personality traits are set around the age of 20 (McCrae \& Costa, 2003), this can potentially happen during the early stages of life. In addition, different personalities can adapt in different ways to a new environment, and it can therefore seem to outsiders as if personalities change, whereas they are merely seeing a reflection of how personalities interact with the new environment.

\section{Data}

\subsection{Dataset}

Our analyses are based on data from HBO-Monitor, a large Internet-based survey administered to recent graduates from universities of applied sciences ${ }^{5}$ in the Netherlands. The Research Centre for Education and the Labour Market (ROA) and Desan Research Solutions carry out a national survey that targets the graduates of all study programmes 1.5 years after completion. The graduates are asked by email to participate in the survey and are given a link and login code. There are 37 universities of applied sciences in the Netherlands (Vereniging Hogescholen, 2018), and the survey covers about 90 per cent of the yearly graduates, with a response rate of about 40 per cent. These higher educational institutions offer a broad set of vocational educational programmes and are more or less equally dispersed throughout the Netherlands. Our study includes four graduation cohorts in the sample

5. The Dutch higher education system is divided into more research-oriented educational institutions, namely, universities $(N=15)$ and higher professional educational institutions, that is, universities of applied sciences $(N=37)$ (Nuffic, 2017). 
(students who graduated in 2007 and 2009, 2010, and 2011). The respondents were contacted twice: 1.5 years after graduation (defined as $t_{0}$ ), and in 2015, between four and eight years after graduation (defined as $t_{1}$ ). For the follow-up survey at $t_{1}$, the postal addresses of the graduates were provided by $80 \%$ of the universities of applied sciences that previously participated at $t_{0}$. Furthermore, among the institutes that did not wish to participate again, only those graduates who indicated they were willing to participate in future surveys were contacted again. The response rate of the follow-up survey at $t_{1}$ is 11.2 per cent (Allen, Belfi, \& Mommers, 2016, pp. 7-10). Only in the follow-up survey did the respondents answer a question with respect to their personality traits.

Our dataset includes all respondents with non-missing data on personality traits and whose place of residence 1.5 years after graduation is still in the Netherlands. We exclude graduates who live in a foreign country ( $N=53$ ), whose municipality of residence is not known $(N=1940)$, and with missing control variables $(N=192)$. This leaves us with 4,500 observations in our sample. Below we present descriptive statistics for our data to gain a better understanding of the sample and show that the mobility behaviour of our chosen subgroup is sufficient for our research purposes. The mobility behaviour we describe below is based on a comparison between the place of residence 1.5 years after graduation $\left(t_{0}\right)$ and the place of residence at the time of completion of the follow-up survey $\left(t_{1}\right)$.

About $14 \%$ of the graduates of universities of applied sciences in our sample were living in a different province (Nomenclature of Territorial Units for Statistics NUTS II, 12 provinces) at $t_{1}$ (four to eight years after graduation), compared to their residence at $t_{0}$ (1.5 years after graduation). The province of Groningen lost most of its graduates, whereas central areas such as Gelderland, Utrecht and NoordBrabant gained the largest share of graduates of universities of applied sciences. At the municipal level, $33 \%$ of the students moved between $t_{0}$ and $t_{1}$. Only $6.4 \%$ of the total sample returned at $t_{1}$ to the same residential location as when they were 16 years old. In addition, with regard to the association between mobility behaviour and personality traits, low scorers on neuroticism are less likely $(p<0.10)$ to move, controlling for personal characteristics (age, age squared, gender, household situation, average grade, and whether seeking a job). Furthermore, high scorers on openness to experience are positively associated $(p<0.05)$ with mobility when these personal characteristics are not controlled for.

Our data reveal differences in the likelihood of moving among graduates from different study fields. Those with a degree in agriculture were slightly more likely to move between municipalities between $t_{0}$ and $t_{1}$, whereas those with a degree in humanities and the arts were less likely to move. Lastly, in line with Faggian, McCann, and Sheppard (2007b), the data also demonstrate that women are more likely to move. 
Due to the relatively short time required to find employment and the relatively good job matches of recent graduates, it might be easy for regions to retain their graduates by preventing them from moving away. ${ }^{6}$ In addition, the Netherlands is a relatively small country, with high population and job densities: commuters travel an average of 24 kilometres daily, which takes approximately 34 minutes (Statistics Netherlands, 2016). This finding indicates that individuals do not necessarily need to move for work-related purposes. Instead personality traits could play a more prominent role in the residential location choice. In this scenario, one might prefer to settle down in a place where the personality profile of the residents matches one's own (Venhorst, 2012; Allen et al., 2009).

\subsection{Variables of interest}

The residential location variable serves as a dependent variable to analyse the role of personality in location choice. The data include information on four residential locations in time: 1) the place of residence at age 16,2 ) the place of residence during the last year of studies, 3) the place of residence 1.5 years after graduation, and 4) the place of residence during the follow-up survey (four to eight years after graduation). These measurements are made at two moments in time: 1.5 years after graduation, defined as t0, and during the follow-up survey (four to eight years after graduation), defined as $\mathrm{t} 1$. For our analyses on location choice, we focus on movement between to and $\mathrm{t} 1$ and control for pre-t0 mobility, since previous mobility is a good indicator of future mobility (Corcoran \& Faggian, 2017; Krabel \& Flöther, 2014; Haapanen \& Tervo, 2012; DaVanzo and Morrison, 1981). We assume that recent graduates are particularly focussed on obtaining a job and become more concerned about the environmental characteristics of their place of residence later in life. See Section 4 for further elaboration regarding our choice to focus on movement between 1.5 years after graduation and four to eight years after graduation.

Personality traits are measured in the follow-up survey. Personality traits are commonly measured using the Big Five personality inventory (BFI), which covers agreeableness $(A)$, conscientiousness $(C)$, extraversion (E), neuroticism (N), and openness to experience (O) (e.g. Costa \& McCrae, 2008; Ashton, 2007). Studies focusing on regional differences in personality often use the 44-item BFI (BFI-44), using a five-point rating scale ranging from strongly disagree (for a value of one) to strongly agree (for a value of five) to test the five-factor personality dimensions (Rentfrow, 2014; Rammstedt \& John, 2007). In our data, personality is self-reported through one direct question about each trait:

6. For the whole sample, at $t_{0,79}$ per cent of the graduates found a job directly after graduation, and 95 per cent found their first job within the first six months, with 83 per cent working a job that matches their field of study. 
To what extent do the following statements apply to you?
(A) I find it important that others like me
(C) I am accurate and efficient
(E) I am outgoing and social to and with others
(N) I remain calm in tense situations $(r)$
(O) I am open to experiences

where $(r)$ indicates that the scale of neuroticism is reversed. Therefore, in the remainder of the paper, a high value for this trait refers to a high level of neuroticism. High values for the other personality traits also refer to high scorers (see also Rentfrow et al., 2015). The answers to these questions are given on a five-point scale, ranging from strong disagreement (a value of one) to strong agreement (a value of five).

Multi-item instruments tend to have psychometric advantages over single-item instruments. Singleitem instruments, however, are shown to be reliable and valid measurements for multi-item instruments and have special advantages in panel studies or large-scale surveys (Rammstedt \& John, 2007; Gosling, Rentfrow \& Swann, 2003). Rammstedt and John (2007) find support for a two-item scale of the BFI (BFI-10) being sufficient for large-scale surveys. In addition, personality traits are often measured at one moment in time. Using a large body of empirical evidence, McCrae and Costa (2003) emphasize that personality follows a fairly stable pattern in adulthood. Trait psychologists define adulthood in the decade between ages 20 and 30 . We therefore assume that the personality traits we measure with a mean age of 32 remain constant over our chosen period in the life course.

Tables 1 and 2 present descriptive statistics for the variables of interest. 
Table 1: Descriptive characteristics based on the follow-up survey at $t_{1}$ (four to eight years after graduation, in 2015)

\begin{tabular}{|c|c|c|}
\hline Variable & $\%$ & $\mathbf{N}$ \\
\hline \multicolumn{3}{|l|}{ Background characteristics } \\
\hline Mean age & 32.4 & 4500 \\
\hline Men & $44.4 \%$ & 1999 \\
\hline Female & $55.6 \%$ & 2501 \\
\hline One-person household & $20.9 \%$ & 941 \\
\hline Two-person household & $73.3 \%$ & 3299 \\
\hline Living with parents & $4.7 \%$ & 213 \\
\hline Different household & $1.0 \%$ & 47 \\
\hline Average grade during graduation & 7.4 & 4500 \\
\hline Currently looking for (other) paid work & $21.4 \%$ & 962 \\
\hline Not currently looking for (other) paid work ${ }^{7}$ & $78.6 \%$ & 3538 \\
\hline \multicolumn{3}{|l|}{ Mobility indicators } \\
\hline $\begin{array}{l}\text { Prior mobility (mobility between municipalities from age } \\
16 \text { to } t_{0} \text { ) }\end{array}$ & $49.4 \%$ & 2237 \\
\hline Mobility $\left(t_{0}-t_{1}\right)$ & $33.2 \%$ & 1559 \\
\hline
\end{tabular}

Source: HBO-Monitor

Table 2: Descriptive sample characteristics of the Big Five personality traits, distributions in percentages, and self-reported answers in response to trait-revealing statements

\begin{tabular}{lrrrrrrr}
\hline Variable & \multicolumn{7}{c}{ Scale 1 = low to 5 = high } \\
& Mean & Std. dev. & $\begin{array}{r}1 \\
\text { Disagree } \\
\text { completely }\end{array}$ & 2 & 3 & 4 & $\begin{array}{r}5 \\
\text { Agree } \\
\text { completely }\end{array}$ \\
\hline Agreeableness & 3.6 & 0.90 & 1.6 & 9.2 & 31.0 & 43.7 & 14.5 \\
Conscientiousness & 4.1 & 0.87 & 0.5 & 5.2 & 16.2 & 42.8 & 35.3 \\
Extraversion & 4.2 & 0.73 & 0.1 & 1.6 & 12.7 & 49.2 & 36.4 \\
Neuroticism (r) & 2.4 & 0.90 & 16.3 & 40.6 & 32.1 & 10.2 & 0.8 \\
Openness to experience & 4.1 & 0.78 & 0.2 & 2.6 & 15.7 & 45.5 & 36.1 \\
\hline
\end{tabular}

Source: HBO-Monitor

\section{Methodology}

First, we use the Getis-Ord $G^{*}$ statistic per municipality $m\left(\mathrm{Gm}^{*}\right)$ to identify the clustering of personality traits across municipalities in the Netherlands (Kondo, 2016). Because of the randomness of the personality traits of individuals, calculations of the mean of each personality trait per municipality and plotting these onto a map could lead to biased conclusions, since random outliers will make it more difficult to observe patterns in the data, especially when the number of observations in one or more municipalities is relatively low. By using a measure for spatial autocorrelation, we can determine patterns of clustering or dispersion in the region and whether the clusters are statistically significant.

7. Note that the majority are not currently looking for a job at either $t_{0}$ or $t_{1}$. 
The $\mathrm{Gm}^{*}$ measure calculates a z-score for each personality trait and area. Higher z-scores indicate a clustering of high values (hot spots) in a certain area, and lower z-scores correspond to lower values (cold spots). The p-value determines whether the value is significant. The measurement not only calculates the values per municipality separately, but also takes the values of neighbouring municipalities into account. We use a binary spatial matrix to identify neighbours, where a value of one indicates a neighbouring area falls within a certain threshold distance (see Section 5.1), and zero otherwise.

For each Big Five trait $B_{m}$ of municipality $m$, the $\mathrm{Gm}^{*}$ statistic is

$$
G_{m}^{*}=\frac{\sum_{n=1}^{N} w_{m n}(\delta) B_{n}}{\sum_{n=1}^{N} B_{n}}
$$

where $\mathrm{N}$ is the total number of municipalities in the Netherlands and the spatial weight $w_{m n}(\delta)$ is the $m n$th element of the spatial weight matrix with threshold distance $\delta$. The z-value of this statistic is then used to identify surrounding municipalities within the critical area, with \pm 1.96 being equivalent to a significance level of $5 \%$, and \pm 1.64 being equivalent to a significance level of $10 \%$.

Second, we present correlations between mean personality traits within municipalities at $t_{1}$ and demographic, economic, physical, political, health, and sociocultural, crime, and religious indicators measured at the Local Administrative Unit II level for municipalities. Our data are mainly from Statistic Netherlands and were measured in 2015. Principal component analysis (PCA) is applied to each subset of macro-level indicators to reduce both the number of variables in the models to be more digestible and any multicollinearity among variables from the same category. We keep the factors with the highest eigenvalue and confirm that they are all larger than one. See Appendices $1 \mathrm{a}$ and $1 \mathrm{~b}$ for overviews of the categorical variables from the PCA and the variables underlying it. In the PCA, if not already a percentage, the variables are transformed into a percentage of the total number of inhabitants per municipality and then normalized.

For the final step in the analysis, we estimate a model in which alternative location options are explicitly taken into account. For example, if there is one city with ample job opportunities but a low level of amenities and one city with few job opportunities but a high level of amenities, the decision between the two choices would depend on individual preferences. If a high scorer on conscientiousness finds job opportunities to be important but attributes less value to amenities, this individual is more likely to choose the location that offers ample job opportunities but fewer amenities, whereas an individual with low conscientiousness would be more likely to choose the other location. 
To model such a decision making process, we apply a discrete choice model by means of a mixed logit model (see also Train, 2003). We propose a model in which individuals are assumed to have chosen a municipality from a fixed set of possible municipalities. Every possible location is then characterized by a variety of location characteristics. While we would ideally include all municipalities in this set of choices, this is not computationally feasible to do for each individual in our dataset. Therefore, we add 30 alternatives per person. Both the place of residence 1.5 years after graduation $\left(t_{0}\right)$ and four to eight years after graduation $\left(t_{1}\right)$, if different, are always included, with the rest of the locations selected via simple random sampling. The dependent variable, the choice of residence, equals one for the place of residence four to eight years $\left(t_{1}\right)$ after graduation, and zero otherwise.

The majority of students of universities of applied sciences study at a nearby institute and still live at their parents' home during their studies (Vereniging Hogescholen, 2018). In addition, Teichert et al. (2018), Haapanen and Tervo (2012) and Busch and Weigert (2010) find that the probability of recent graduates leaving the study region is the highest in the two years following graduation. By focusing on mobility and the location choices between places of residence 1.5 years and four to eight years after graduation, we try in particular to model the settlement behaviour of those who made a decisive location choice, independent of the location of the universities of applied sciences or the parents' place of residence. For the purpose of this study, we define the location choice as a voluntary choice that consists of two major stages that are interdependent upon one another and influenced by personal background characteristics, personality traits, and environmental characteristics. One stage defines the choice of whether one stays or moves. The other stage involves the choice of the place of residence, where individuals can choose between many different municipalities.

We include probability weights in our model to account for the unequal probabilities of a place being selected from the fixed set of location choices, since the place(s) of residence is always included, whereas the alternatives are chosen with a fixed probability. We control for a list of personal background characteristics $\boldsymbol{P}_{\boldsymbol{i}}$ (age, age squared, gender, household composition, grades, and whether seeking a job ${ }^{8}$ ).

Our main goal is to examine the interplay between personality traits and environmental characteristics at the Dutch municipality level in the settlement behaviour of recent graduates of universities of applied sciences. Denote $\boldsymbol{E}_{\boldsymbol{m}}$ as the environmental characteristics of municipality $m$ four to eight years after graduation and $\boldsymbol{B}_{\boldsymbol{i}}$ as the vector of Big Five traits of individual $i$, assumed to be constant in the time period our model covers. The main effect of $\boldsymbol{E}_{\boldsymbol{m}}$ denotes the general

8. Since the model size is a concern, we do not include the field of study as a personal background variable. Initial findings moreover suggest that it hardly matters in explaining location choice. 
desirability of area characteristics (e.g. those defined in Appendix 1a). The main effect of the vector $\boldsymbol{B}_{\boldsymbol{i}}$ will capture municipality-specific desirability per personality trait. We are especially interested in the channels through which personality affects location choice. Therefore, the most important variable of interest is the interaction of area-specific characteristics with personality traits, $\boldsymbol{E}_{\boldsymbol{m}}{ }^{*} \boldsymbol{B}_{i}$. For example, if people with a high level of agreeableness do indeed move to areas with more greenery, we expect to see a positive and statistically significant effect of the interaction between the level of physical green space within a municipality and the level of agreeableness. Similarly, we also interact $\boldsymbol{P}_{\boldsymbol{i}}$ with environmental characteristics to control for heterogeneity in location preferences resulting from personal background characteristics.

The results are driven not only by the attractiveness of the residential choice (pull factors), but also by the initial place of residence after graduation and possible deficits that increase the chances of moving away to another municipality (push factors). Let $m 0$ denote the base state for the place of residence for individual $i 1.5$ years $\left(t_{0}\right)$ after graduation. We include the environmental characteristics of the base state $\left(\boldsymbol{E}_{\boldsymbol{m} \mathbf{0}}\right)$ and its interaction with personality $\left(\boldsymbol{E}_{\boldsymbol{m} \mathbf{0}} * \boldsymbol{B}_{\boldsymbol{i}}\right)$ to refer to heterogeneous push factors of the environmental characteristics with respect to the personality traits. Negative coefficients for the environmental characteristics in the base state should be interpreted as push factors that incite people to move away. Positive coefficients of the pull factors $\left(\boldsymbol{E}_{\boldsymbol{m}}\right.$ and $\left.\boldsymbol{E}_{\boldsymbol{m}} * \boldsymbol{B}_{\boldsymbol{i}}\right)$ will incite people to move to their respective municipalities. Lastly, we also include a mobility vector $\boldsymbol{\varphi}_{\text {im }}$ that includes the distance variable $d_{i m}$, its square $d_{i m}^{2}$, and a dummy $\zeta_{i m}$ that signifies prior mobility between municipalities in the period between 16 years of age and $t_{0}$. For each potential choice of municipality $m$, this variable measures the distance (in kilometres) between $m$ and individual $i$ 's choice of residence at time $t_{1}$. The idea behind this variable is that moving to a residence far away involves a cost. Berck et al. (2016) point out that the residential location choices they observe are strongly determined by one's initial residence and are restricted to a few destinations, given a marginally increasing penalty related to moving to a residence farther away from one's current residence.

The final model can be written as follows:

$$
\text { choice }_{i m}=\boldsymbol{X}_{\boldsymbol{i m}} \boldsymbol{\beta}+\boldsymbol{Z u}_{\boldsymbol{i}}+\boldsymbol{\varepsilon}_{\boldsymbol{i m}}
$$

where $i$ denotes an individual in our dataset; $m$ is a municipality from the choice set of all municipalities in the Netherlands; choice $_{i}$ is a dummy that is equal to one if individual $i$ lives in municipality $m$ (at $t_{1}$ ), and zero otherwise; $\boldsymbol{X}_{i m}$ is a matrix of independent variables; $\mathbf{Z}$ is the unstructured covariate matrix for the random effects $\boldsymbol{u}_{\boldsymbol{i}}$ for individual $i$; and $\varepsilon_{i m}$ is a vector of 
errors. The vector $\boldsymbol{\beta}$ denotes the effects of the above-mentioned variables belonging to the matrix $\boldsymbol{X}_{i m}$.

We can further split up $\boldsymbol{X}_{\text {im }}$ into separate components, as follows:

$$
\boldsymbol{X}_{i m}=\boldsymbol{\varphi}_{i m}+\boldsymbol{P}_{\boldsymbol{i}}+\boldsymbol{E}_{\boldsymbol{m} 0}+\boldsymbol{E}_{\boldsymbol{m}}+\boldsymbol{B}_{\boldsymbol{i}}+\left(\boldsymbol{E}_{\boldsymbol{m} 0}+\boldsymbol{E}_{\boldsymbol{m}}\right) *\left(\boldsymbol{P}_{\boldsymbol{i}}+\boldsymbol{B}_{\boldsymbol{i}}\right)
$$

where $m 0$ is the place of residence for individual $i 1.5$ years after graduation, $P_{i}$ constitutes the background characteristics of individual $i$, and $\boldsymbol{\varphi}_{i m}$ is the mobility vector that comprises the distance and prior mobility between $m 0$ and $m$.

Furthermore, $\boldsymbol{E}_{\boldsymbol{m} \boldsymbol{0}}$ and $\boldsymbol{E}_{\boldsymbol{m}}$ denote the area characteristics of municipality $m 0$ and $m$, respectively, while $\boldsymbol{E}_{\boldsymbol{m} \boldsymbol{0}} * \boldsymbol{B}_{\boldsymbol{i}}$ and $\boldsymbol{E}_{\boldsymbol{m}} * \boldsymbol{B}_{\boldsymbol{i}}$ denote the interaction effects between the two sets of area characteristics and the vector of personality traits of individual $i$. The main aim of our paper is to estimate the heterogeneous effects of the environmental factors with respect to these personality traits on location choice.

\section{Personality traits and environmental characteristics}

\subsection{Geographical distribution of personality traits over time}

We first examine the extent to which aggregated levels of personality traits are geographically clustered throughout the Netherlands at residential locations at 1.5 years $\left(t_{0}\right)$ and four to eight years $\left(\mathrm{t}_{1}\right)$ after graduation, using hot and cold spot analysis.

The Getis-Ord Gm* statistic depends on the size of the spatial distance matrix used to identify spatial neighbours. Since no prior research suggests an ideal threshold distance, we consider four possible distances: 25, 50, 75, and 100 kilometres. See Appendix 2 for the results of this test. The main conclusions are robust for 50 and 75 kilometres. However, because we measure distance linearly, the north-western portion of the Netherlands becomes grouped with parts of the north across the water for these larger distances. This is because this part of the Netherlands is connected via a long dike from North Holland to Friesland. The results therefore change according to when the distance threshold is increased. Therefore, all the maps in this paper are based on a cutoff of 50 kilometres. 
Figure 1: Heat maps of the geographical distributions of the personality traits of recent graduates of universities of applied sciences in the Netherlands per municipality 1.5 years and four to eight years after graduation

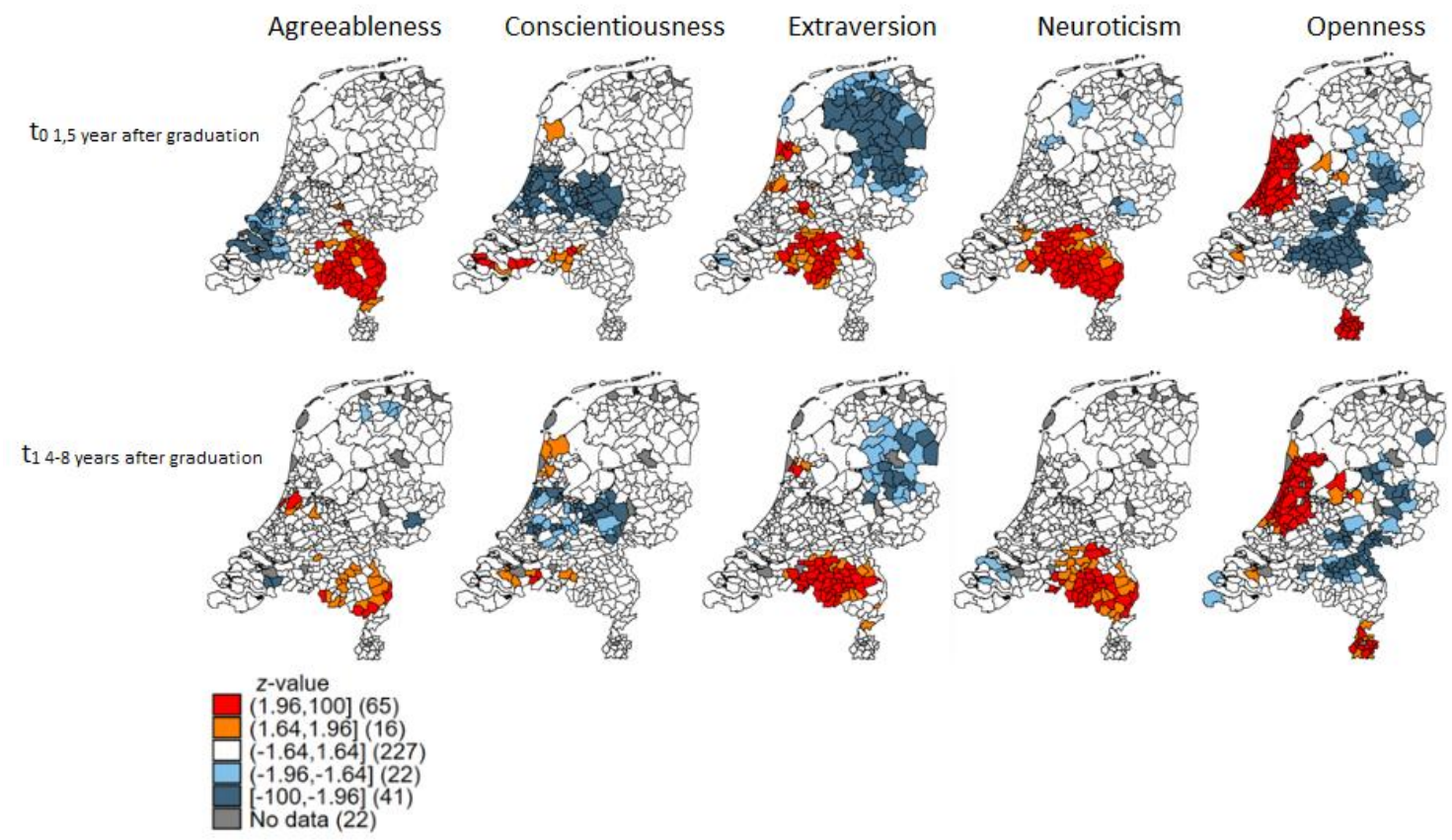

Note: The value of 1.96 is equivalent to $p<0.05$ and 1.64 is equivalent to $p<0.1$.

The first row of Figure 1 shows the distribution of personality traits as measured by the residential location at $t_{0}$. The second row uses the residential location at $t_{1}$. The map in the first column in the upper left shows high levels of agreeableness in the south (parts of the provinces of Limburg and North Brabant) of the Netherlands. This personality trait characterizes itself by trust, sincerity, modesty, and cooperation. This would suggest that the social ties between the communities in the south of the Netherlands are stronger compared to those in other regions (Rentfrow, 2014). The provinces of Zeeland and South Holland, located in the southwest of the country, next to the western Dutch coastline, reveal an opposite image: respondents residing in this region score significantly lower on agreeableness, a personality trait that is associated with rudeness and harshness (Ashton, 2007). The geographical clustering of agreeableness becomes more blurred at $t_{1}$. Furthermore, high values for agreeableness now seem to be scattered in the province of North Holland (i.e. in the west of the country), whereas we find low scorers on agreeableness in some northern and eastern parts of the Netherlands at $t_{1}$.

The second column of Figure 1 shows the geographical distribution of the conscientiousness trait. High scorers on this trait are self-disciplined, responsible, systematic, and hardworking, on average (Ashton, 
2007). We find high scorers in parts of the provinces of North Brabant, Zeeland, and North Holland, while respondents living in the middle and midwest of the Netherlands (Randstad area and the provinces of Flevoland and Gelderland) score significantly lower. We find a similar distribution in the follow-up survey.

The third column in Figure 1 shows the spatial clustering of the personality trait of extraversion, revealing a dichotomy prevailing in the country. Recent graduates living in the south (North Brabant, Limburg) or in the Randstad area (which also includes some parts of the province of North Holland) tend to be significantly more sociable, talkative, passionate, enthusiastic, and energetic, while those living in the northern provinces (including the Wadden Islands), the east of the country, and some municipalities in the province of Zeeland tend to be more reserved and passive in terms of personality traits (Ashton, 2007). We find relatively comparable results at $t_{1}$, however, the high scorers around the Randstad area seem to have disappeared. The image shown is in line with the widely held view that traits such as emotionality are more prevalent in the south than in the north (Pennebaker, Rime, \& Blankenship, 1996). In the Netherlands, these differences are expressed in the 'hardness' of the people to the north of the Rhine River and the 'softness' of the southerners to the south of the Meuse. The Rhine and Meuse are the longest rivers in the Netherlands and divide the country into north and south (Cornips, 2018; Cornips \& Knotter, 2018). In addition, previous studies find that high scorers on extraversion tend to live in more culturally diverse areas and to have larger social networks (Jokela, 2009, 2014).

Since religion shapes people's values, fosters prosocial behaviour, and increases social investment (Putnam and Campbell, 2012; Rentfrow et al., 2008), we argue that it could potentially explain the differences in extraversion found between the north and south. There used to be a clear divide between the Protestants (in the north) and the Catholics (in the south) about a century ago, and deeply rooted beliefs and values could have been passed on to the next generations. Protestants are generally viewed as being more individualistic and independent, whereas Catholics appear to be more collectivistic. Furthermore, compared to Protestants, Catholics tend to participate in religious gatherings for more extrinsic reasons, such as for social support or celebrations (van Elk, Rutjensa, \& van Harreveld, 2017). If culture plays a role in the emergence of geographical differences in personality, then the deeply rooted religious differences between the north and south of the Netherlands could explain part of the differences found. Furthermore, religious differences are still found today in the Netherlands (Schmeets, 2016).

9. Some areas in the Randstad area are Catholic, but this finding is also in line with the hot spots at t0. 
The fourth column in Figure 1 shows the distribution of the personality trait neuroticism. Recent graduates who live in the provinces of North-Brabant and Limburg and some municipalities in the province of South Holland tend to be more anxious, moody, and possessive, whereas those living in a few municipalities in the provinces of Zeeland and Gelderland and in the northern part of the Netherlands tend to be more relaxed and easygoing in terms of this personality trait (Ashton, 2007). However, we find very few spots for low scorers on this trait. The image is more blurred in the second row, at $\mathrm{t}_{1}$; however, the division revealed at $\mathrm{t}_{0}$ persists for high scorers.

With respect to the fifth and last column in Figure 1, for openness to experience, we find significant and positive results for graduates living in the west of the country (north and south Holland), in the southernmost part of the province of Limburg, and in a few municipalities in Zeeland, Flevoland, and Gelderland. Respondents living in the northeast of the country (the provinces of Drenthe, Overijssel, and Gelderland) and parts of North Brabant and Zeeland and a few municipalities of the northern part of the province of Limburg score low on openness to experience, suggesting that these respondents are more conventional and more shallow (Ashton, 2007). A similar image emerges at $t_{1}$. Most of the areas scoring high on openness to experience are considered the most urbanized areas in the Netherlands. The results are in line with those of previous studies (Rentfrow et al., 2015; Jokela et al., 2015).

We additionally run paired t-tests to determine whether the mean differences between the rows are statistically significant. The results between 1.5 years $\left(t_{0}\right)$ and four to eight years $\left(t_{1}\right)$ after graduation are significantly different at the $5 \%$ level. The differences remain significant after restricting the sample size to a minimum of 20 graduates per municipality. These results indeed show that the match between one's personality and the mean personality of the last residential location becomes weaker compared to the match measured 1.5 years after graduation. This finding could indicate that personality sorting is not the main factor driving the geographical mobility of recent graduates when they make a career some years after graduation. ${ }^{10}$

\subsection{Relationship between personality traits and environmental factors}

In this section, we present correlations between mean personality traits and environmental characteristics at the municipality level at $t_{1}$ to understand how personality traits interact with the environment. By accounting for local environmental characteristics at the municipality level, such as the population density, physical appearances, cultural diversity, and amenities (number of bars, restaurants, museums, etc.), we aim to provide refined measures of locations that could be related to

10. Recall that personality traits are measured at $t_{1}$, whereas we find evidence of greater geographical clustering of these traits at $t_{0}$. 
the attractiveness of a place. Table 3 gives an overview of the relationship between personality traits and the environmental factors revealed in the PCA of the underlying environmental characteristics (see Appendix 1a). Higher values for these environmental factors indicate more favourable demographics, better economic viability, a greener physical environment, a more nationalistic political climate, better health, a more attractive sociocultural environment, a higher crime level, or a more religious environment. An overview of the results regarding the relationship between the Big Five personality traits and the indicators of the eight environmental factors is provided in Appendix 3 .

Table 3: Correlations between mean personality traits and environmental factors at the municipality level at $\mathrm{t}_{1}$

\begin{tabular}{|c|c|c|c|c|c|}
\hline Environmental factor & A & C & E & $\mathbf{N}$ & 0 \\
\hline $\begin{array}{l}\text { 1. } \begin{array}{l}\text { Demographic } \\
\text { development }\end{array}\end{array}$ & - & $-0.057^{* * *}$ & - & - & $0.070 * * *$ \\
\hline 2. Economic viability & $0.024 *$ & $-0.054 * * *$ & - & - & $0.068 * * *$ \\
\hline 3. Physical green space & - & - & $0.022 *$ & - & $0.022 *$ \\
\hline 4. Political populism & - & $0.039 * * *$ & - & - & - \\
\hline 5. Health & $-0.034 * * *$ & $0.030 * *$ & - & $-0.025^{* *}$ & - \\
\hline $\begin{array}{l}\text { 6. Sociocultural } \\
\text { attractiveness }\end{array}$ & - & $-0.057^{* * *}$ & - & - & $0.074^{* * *}$ \\
\hline 7. Crime level & - & $-0.028^{* *}$ & $0.021^{*}$ & - & $0.077^{* * *}$ \\
\hline 8. Religiosity & - & - & $-0.028^{* *}$ & - & $-0.042 * * *$ \\
\hline
\end{tabular}

Note: In this table, A represents agreeableness, C conscientiousness, E extraversion, $\mathrm{N}$ neuroticism, and $\mathrm{O}$ openness to experience.

$* * * p<0.0 .1, * * p<0.05, * p<0.1$

All the environmental factors measured at the municipality level and listed in Table 3 show associations with one or more personality traits. The strongest results are found for conscientiousness and openness to experience. The relationship between conscientiousness and environmental characteristics suggests that this trait is more likely to occur in more suburban and rural areas, surrounded by a higher share of the elderly, with a lower population density, fewer economic hubs, a lower density of amenities and less crime, areas with more political populism, and with better health. The correlation results are in line with previous literature (see also Section 2.2), except for the environmental factor for economic viability. We will discuss this relationship once more in the next section on the empirical results for the discrete model of location choice. Except for the positive correlation with physical green space, the findings for the personality trait openness to experience (artistic, curious, and imaginative) are also in alignment with previous studies and are shown to be related to a more urban lifestyle, as indicated by a denser demographic and economic composition, more amenities and facilities in the proximity, higher crime levels, and less religiosity.

We find only a few associations between agreeableness, extraversion, and neuroticism, on the one hand, and the various environmental factors, on the other. Moreover, these results are generally 
statistically less significant. Only the positive association between agreeableness and health is strongly significant and in line with the previous literature (Rentfrow et al., 2008). We note similarities in the correlations between the personality traits and the environmental factors, such as conscientiousness and its correlation with the environmental factors demographic development, economic viability, and sociocultural attractiveness. Hence, we test for correlations between the environmental factors themselves.

Table 4 shows that demographic, economic, sociocultural, and crime factors have strong correlations (above 0.8) with each other. This result indicates that the effects of these four factors cannot be disentangled. The variables are all related to living in an urbanized environment. To avoid multicollinearity, we focus only on economic viability. We do so because most of the literature on the mobility of recent graduates concludes that new, highly educated labour market entrants are attracted to economically prosperous environments (see Section 2.1), and less is known about the role the other variables play in the location choices of recent graduates.

Furthermore, there is a strong correlation of 0.79 between health and political populism. We opt to only include political populism, because there is a low correlation between this factor and economic viability relative to health. Hence, our model includes the following four factors: economic viability, physical green space, political populism, and religiosity. Table 4 further shows that the correlations between location choice and these environmental factors are mainly low. Economic viability reveals the strongest correlation. 
Table 4: Correlations between environmental factors and the location choices of the recent graduates of universities of applied sciences at $t_{1}$

\begin{tabular}{|c|c|c|c|c|c|c|c|c|c|}
\hline \multicolumn{2}{|c|}{ Environmental factor } & \multirow{2}{*}{$\frac{\text { Dem. }}{1}$} & \multirow[t]{2}{*}{ Eco. } & \multirow[t]{2}{*}{ Phy. } & \multirow[t]{2}{*}{ Pol. } & \multirow[t]{2}{*}{ Hea. } & \multirow[t]{2}{*}{ Soc. } & \multirow[t]{2}{*}{ Cri. } & \multirow[t]{2}{*}{ Rel. } \\
\hline 1. & Demographic development & & & & & & & & \\
\hline 2. & Economic viability & $-0.93 * * *$ & 1 & & & & & & \\
\hline 3. & Physical green space & $-0.37 * * *$ & $-0.24 * * *$ & 1 & & & & & \\
\hline 4. & Political populism & $-0.29 * * *$ & $-0.38 * * *$ & $-0.17 * * *$ & 1 & & & & \\
\hline 5. & Health & $-0.43 * * *$ & $-0.53 * * *$ & $-0.13 * * *$ & $0.79 * * *$ & 1 & & & \\
\hline 6. & Sociocultural attractiveness & $0.95^{* * *}$ & $0.88 * * *$ & $-0.39 * * *$ & $-0.20 * * *$ & $-0.31 * * *$ & 1 & & \\
\hline 7. & Crime level & $0.88 * * *$ & $0.82 * * *$ & $0.28 * * *$ & $0.13^{* * *}$ & $-0.28 * * *$ & $0.87^{* * *}$ & 1 & \\
\hline \multirow[t]{2}{*}{8.} & Religiosity & $-0.01 * * *$ & $-0.09 * * *$ & $-0.07 * * *$ & $-0.23 * * *$ & $-0.13 * * *$ & $-0.11 * * *$ & $-0.05 * * *$ & 1 \\
\hline & Location choice & $0.17^{* * *}$ & $0.17 * * *$ & $-0.03 * * *$ & $-0.05 * * *$ & $-0.06 * * *$ & $0.17^{* * *}$ & $0.16 * * *$ & -0.00 \\
\hline
\end{tabular}

$* * * p<0.01, * * p<0.05, * p<0.1$ 


\section{The role of personality in location choice}

The empirical analyses in the previous sections reveal differences in the regional clustering of personality traits and show significant correlations between environmental factors, on the one hand, and personality traits, on the other. In this section, we focus on the role of personality and its interaction with environmental factors when explaining the residential location choices of recent graduates of universities of applied sciences in the Netherlands. We therefore analyse the movements between different locations (municipalities) between 1.5 years $\left(t_{0}\right)$ and four to eight years $\left(t_{1}\right)$ after graduation.

In Figure 1, we show that the regional clustering of personality traits significantly weakens some years after graduation. This finding could suggest that the personality traits of young people are clustered by inherited or culturally determined factors and weaken when they move to other areas, for example, for work. This argument, in turn, suggests that personality sorting does not have the predominant impact on residential location choice some years after graduation. Nevertheless, if any form of sorting takes place, we expect people with similar personality traits to move to areas where some environmental factors match particular personality traits, thereby forming clusters of specific personality traits. However, this does not answer the question of the channels through which the effect takes place, or how large their impact is.

We aim to shed more light on the impact of environmental factors on the location choice of graduates with differing personality traits by estimating the discrete choice model we describe in Section 4. In Table 4, we find several environmental variables to be highly correlated with each other. We therefore reduce the number of environmental factors in the model from eight to four. We split the results into two tables: Table 5.1 shows the push effects of the four environmental factors, while Table 5.2 shows their pull effects. ${ }^{11}$ We focus on the main effects of the environmental factors, as well as their interaction with the Big Five personality traits.

11. The full regression table can be found in Appendix 7 . 
Table 5.1: Push effects on location choice (a location choice dummy) and the impact of environmental variables, with additional environmental effects due to interactions with the individual Big Five personality traits (A, C, E, N, and O).

\begin{tabular}{|c|c|c|c|c|c|c|c|c|c|c|c|c|}
\hline & & \multirow{3}{*}{$\begin{array}{c}\text { Main } \\
\text { push effects } \\
\left(t_{0}\right)\end{array}$} & \multicolumn{10}{|c|}{ Interaction effects with the Big Five personality traits } \\
\hline & & & \multicolumn{2}{|r|}{ A } & \multicolumn{2}{|c|}{$\mathrm{C}$} & \multicolumn{2}{|c|}{$\mathrm{E}$} & \multicolumn{2}{|c|}{$\mathrm{N}$} & \multicolumn{2}{|c|}{$\mathrm{O}$} \\
\hline \multicolumn{2}{|c|}{ Environmental variables } & & Low & High & Low & High & Low & High & Low & High & Low & High \\
\hline 1. & Economic viability & $-0.620 * * *$ & & & & & & & & & & \\
\hline 2. & Physical green space & & & & & & & & & $-0.011 * *$ & & $0.039 *$ \\
\hline 3. & Political populism & & & & & & & & & & $0.135^{*}$ & \\
\hline 4. & Religiosity & & & & & & & & $-0.029 * *$ & & & \\
\hline
\end{tabular}

Note: In this table, A represents agreeableness, $\mathrm{C}$ conscientiousness, E extraversion, $\mathrm{N}$ neuroticism, and $\mathrm{O}$ openness to experience.

$* * * \mathrm{p}<0.01, * * \mathrm{p}<0.05, * \mathrm{p}<0.1$

Controlled for distance, distance ${ }^{2}$, prior mobility, main effects of the Big 5 and personal characteristics (age, age ${ }^{2}$, gender, household situation, average grade and looking for job). For interaction variables, we report the effects for high scorers ( $4=$ agree $\&$ and $5=$ strongly agree) and for low scorers $(1=$ strongly disagree $\&$ and $2=$ disagree). The base category is set to 3 . Numbers represent the estimated coefficients of the main model.

Mind that positive or negative effects can be based on either high or low scorers on personality trait scores. 
Table 5.1 presents the results of the likelihood of being pushed away from the residential location in $t_{0}$. A positive coefficient indicates a greater likelihood of being pushed away from a location. A negative coefficient points to a lower chance of moving to a new location (i.e. from $t_{0} t_{0} t_{1}$ ), since one is less likely to be pushed away from a residential location at $t_{0}$ that strongly exhibits the respective environmental factor.

The first column of the results in Table 5.1 shows the main effects of the environmental factors, regardless of the personality traits, on the residential location choice 1.5 years $\left(t_{0}\right)$ after graduation. With regard to these main effects, we find a coefficient of -0.62 if economic viability increases by one standard deviation (and a decrease of $17.0 \%$ if we look at average marginal effects ${ }^{12}$ ). There are no statistically significant coefficients for the other three main environmental factors.

The results in the columns of Table 5.1 following the main effects explore the heterogeneity of the impact of the environmental factors with respect to the personality traits of recent graduates. We estimate the impact of the interaction effects between the personality traits and the environmental factors on residential location choices. We distinguish between low and high scorers on personality traits. We find statistically significant effects for the Big Five traits of neuroticism and openness to experience in interaction with several environmental factors. This result implies that these two personality traits in particular reinforce the positive or negative impact of the environmental factors.

High scorers on neuroticism are less likely to be pushed away by more greenery at the location at $t_{0}$ (0.011). Furthermore, low scorers on neuroticism are less likely $(-0.029)$ to move away from regions with greater religious presence in $t_{0}$. For high scorers on the personality trait openness to experience, we find that recent graduates are more likely $(0.039)$ to be pushed away from their residential location at $t_{0}$ in the presence of more greenery. Less green space can indicate more urban living, which is in line with previous studies that find that high scorers on openness to experience are more prevalent in urban areas (Rentfrow et al., 2015; Allik et al., 2009). Furthermore, we find that low scorers on openness to experience are more likely to leave an area if political populism increases (0.135).

12. We compute the average marginal effects for the main effects and the interaction effects. The marginal effects of the interaction variables are similar to the coefficients of the model (Tables 5.1 and 5.2) when $p$ $<0.05$ (all values would fall within its confidence interval), whereas some variables with $p<0.1$ become less significant. 
Table 5.2: Pull effects on location choice (a location choice dummy) and the impact of environmental variables, with additional environmental effects due to interactions with the individual Big Five personality traits (A, C, E, N, and O).

\begin{tabular}{|c|c|c|c|c|c|c|c|c|c|c|c|c|}
\hline \multirow{3}{*}{\multicolumn{2}{|c|}{ Environmental variables }} & \multirow{3}{*}{$\begin{array}{c}\text { Main } \\
\text { pull effects }\end{array}$} & \multicolumn{10}{|c|}{ Interaction effects with the Big Five personality traits } \\
\hline & & & \multicolumn{2}{|r|}{ A } & \multicolumn{2}{|r|}{ C } & \multicolumn{2}{|c|}{$\mathrm{E}$} & \multicolumn{2}{|c|}{$\mathrm{N}$} & \multicolumn{2}{|c|}{0} \\
\hline & & & Low & High & Low & High & Low & High & Low & High & Low & High \\
\hline 1. & Economic viability & $0.111 * *$ & & & & $-0.009 * *$ & & & & & & \\
\hline 2. & Physical green space & & & $0.008^{*}$ & & & & & & & & \\
\hline 3. & Political populism & & & & $-0.037^{* *}$ & & & & & & & \\
\hline 4. & Religiosity & $0.190^{* * *}$ & & & $-0.020 *$ & & & $-0.014 *$ & & & & \\
\hline
\end{tabular}

For definitions and notes, see Table 5.1 . 
Table 5.2 presents the pull effects of the environmental factors in the model, again in interactions with recent graduates who move to a new residence. A positive coefficient for a pull factor indicates a greater likelihood of being pulled towards a location. The first column of results shows the main effects of the environmental factors on location choice, regardless of the personality traits, and on location choice four to eight years $\left(t_{1}\right)$ after graduation. Positive coefficients for $t_{1}$ serve as pull factors indicating a greater likelihood of settling down in a new location where the respective environmental factors are strongly present. The main effects indicate that recent graduates are 0.111 more likely to be pulled towards a location $\left(t_{1}\right)$ with greater economic viability (a marginal effect of $8.5 \%$ ). In addition, we find a coefficient of 0.190 (a marginal effect of 1.6\%) for the main effect of religiosity. This result indicates that recent graduates are more likely to be pulled towards a location $\left(t_{1}\right)$ with greater religiosity. Note that, for certain scorers of personality traits, the effect of religiosity is diminished. Since we cannot control for a student's religion, this result could be due to the stronger preference of more religious students to move to municipalities with a higher level of religiosity, which corresponds more to their own. This leads, on average, to a pull effect for municipalities with greater religiosity.

For high scorers on agreeableness, the probability of settling down in a location with more greenery $\left(t_{1}\right)$ is increased by 0.008 . Although this effect is relatively small, it is in line with previous literature suggesting that agreeable people are more likely to settle in areas with more green space (Jokela et al., 2015) and less crime (Rentfrow et al., 2008). For high scorers on conscientiousness, we find that the likelihood of settling in an area $\left(t_{1}\right)$ decreases with higher economic viability, with a coefficient of -0.009. Our findings are in contrast with those of Lee (2017) and Obschonka et al. (2013), who find conscientiousness to be positively related to innovation rates (patenting) and state-level entrepreneurial activity, respectively. However, Ayhan et al. (2017) find that high scorers on conscientiousness are less likely to move from rural to urban areas. Even though conscientiousness tends to be associated with high productivity, it does not necessarily indicate that high scorers on this trait also prefer living in economically viable areas. Furthermore, we find that low scorers on conscientiousness are less likely to settle in an area $\left(t_{1}\right)$ with greater political populism $(-0.037)$. Conscientiousness is positively related to votes for conservative candidates in general elections in England and negatively related to votes for labour parties (Rentfrow et al., 2015). In addition, low scorers on this trait are less likely to settle down in an area with greater religiosity $(-0.20)$. To the best of our knowledge, no previous study finds a relation between religiosity and conscientiousness. Additionally, high scorers on extraversion are less likely to be pulled $\left(t_{1}\right)$ to an environment with greater religiosity (-0.014). 
In sum, the results suggest that the largest effect comes from the economic environmental variable, with both strong push and pull effects. Even though the effect sizes and significance levels differ greatly for the interaction variables between personality traits and environmental factors, the findings indicate that personality does affect the attractiveness of certain environmental characteristics and, therefore, also influences location choice.

We additionally apply a series of robustness checks. First, in Appendix 4, we present the results for the model that includes all eight environmental variables. In this model, economic viability remains the strongest main predictor, while most effects are merely weakly significant. Furthermore, due to multicollinearity, some expected effects weaken or disappear and are not robust. Second, in Appendix 5 , we treat the Big Five personality traits as continuous variables, instead of dummy variables, with the middle of the scale as the base value. We would then expect the findings for high scorers of a personality trait to show the reverse effect for low scorers (and vice versa). We find quite a few changes compared to our earlier results in Appendix 4. This suggests that the treatment of personality traits as continuous variables is not the correct specification for our data. Lastly, in Appendix 6, we estimate the effect of each Big Five trait separately instead of all together, as in the main model. The conclusions hardly change from those of the empirical estimations.

\section{Discussion and conclusion}

The determinants of spatial mobility and the residential settlement of graduates have been extensively explored in economics and other social sciences. Economic determinants often appear to be dominant in studies focusing on the settlement behaviour of recent graduates. This is not surprising, since most studies focus only on human capital migration models. Over the last years, studies have also started to focus on non-economic migration models to explain graduate mobility. They have found that, for example, social ties, the quality of life, regional familiarity, and time spent in the study region play a role, too. This result suggests that the choice of residence is often driven by the interplay of many determinants and cannot be reduced to a few determinants operating in isolation.

In exploring the determinants of settlement behaviour, studies have somewhat overlooked the role of psychological features in explaining location choice. Research in psychology has recently started to devote increasing attention to the role of personalities in spatial mobility. These studies not only find that individuals with some personality traits are more likely than the average to be spatially mobile, but also reveal robust differences between the mean personality traits of geographical areas. The obvious appearance of different clusters of personalities in such studies makes it reasonable to 
suppose that particular areas also attract specific groups of people. However, to date, these studies have primarily focused on the correlation between personality traits and environmental factors and use cross-sectional data, which limits the possibility of empirically testing whether geographical differences in personality are based on personality sorting.

The present study aims to extend previous work and therefore first focuses on the geographical distribution of the personality traits of recent graduates of universities of applied sciences and tests the extent to which these evolve over time. The findings demonstrate a clear geographical distinction of the personality profiles of recent graduates of universities of applied sciences between Dutch regions. The results, for example, demonstrate robust clusters of high scorers on extraversion in the southern part of the Netherlands and in the Randstad area, whereas low scorers of this trait are significantly distributed in the north and east of the country 1.5 years after graduation. The geographical distribution of this personality trait remains relatively visible, but weakens statistically over time. This finding suggests that personality sorting is not the main factor causing the geographical clustering of graduates. One of the explanations could be that the differences in the geographical clustering of personality traits are a result of deeply rooted cultural differences between Dutch regions, and that settlement in a different place (e.g. due to job place sorting) weakens the differences in these regional cultures.

In the next step in our analysis, we show the correlations between personality traits and eight different environmental factors. Agreeableness and neuroticism are related to two and one environmental factor, respectively. The three remaining personality traits show correlations with more environmental factors. Those graduates maintaining an extraverted and open lifestyle seem to be more prevalent in urban environments, in contrast to graduates scoring high on conscientiousness, who seem to prefer a rural or suburban way of life. Different personalities could thus value residential locations in different ways.

To better understand the role of personality and its interaction with the environment in explaining the residential location choices of the recent graduates of universities of applied sciences, we apply a discrete choice model as a last step in the analysis. We reduce the number of environmental factors in this model because of multicollinearity. The largest coefficients in the model come from the main effects, suggesting that greater economic viability makes recent graduates of universities of applied sciences less likely to be pushed away, or more attracted to settle down in their current location or a new location. Furthermore, greater religiosity in a municipality makes graduates more likely to be pulled towards it. Furthermore, we finding that personality affects the attractiveness of several environmental factors and therefore does influence location choice as well. The effect sizes vary for 
the interaction between personality traits and the environmental indicators of residential location choice.

The multidisciplinary paradigm used in this paper is useful for analysing the extent to which environmental factors and personality traits are related and places studies on location choice within a larger context. It furthermore provides a better understanding of the influence that environmental factors can have on residential behaviour. We want to stress, however, that more research is needed and that our study is of an exploratory nature.

\section{Future research}

The analyses in our paper allow us to examine the role of personality traits in settlement behaviour and whether differences in personality profiles between regions emerge via personality sorting. The latter has not been explored in previous studies. The substantive and statistically significant heat maps showing the distributions of personalities throughout the Netherlands are intriguing, especially considering that we only roughly assess personality profiles. It would nevertheless be interesting to test our findings with richer scales measuring personality traits. Research on cross-national personality differences potentially has better psychometric advantages due to the use of richer scales (Gosling et al., 2003). Lang and colleagues (2011), for example, suggest that the 15-item BFI of personality dimensions measures robust and reliable outcomes. Furthermore, Gosling et al. (2003) acknowledge the use of a 10-item personality inventory. In addition, Rammstedt and John (2007) already find evidence indicating that a two-item BFI scale is sufficient for a large-scale survey. Additionally, panel data measuring personality traits over time can provide a better understanding of the extent to which personality traits affect or are affected by the environment. Furthermore, it would be interesting to focus on particular combinations of personality traits instead of analysing traits separately. For example, the southern part of the Netherlands scores high on agreeableness and high on extraversion.

In addition, individuals often rate themselves by their own evaluation of personality traits, but can also give their views on the personality profiles of different regions. This information could be used in addition to self-reports of their own personality traits for a broader view (Allik \& McCrae, 2004). McCrae and colleagues (1998), however, find no differences between observer ratings and selfreported personality traits among Hong Kong- and Canadian-born Chinese.

The collection of data to study whether the current clustering of personalities traits found throughout the Netherlands is relevant in terms of generalization to average Dutch society, since this study focuses merely on graduates from universities of applied sciences. It could therefore be of interest to 
additionally compare how the target group in our study relates to mean regional personality traits. A comparison with recent graduates in other countries, especially in countries where spatial mobility is greater and commuting distances longer, would be of further interest.

Lastly, the regional clustering of personality traits seems to slightly fade with time. This could point to an underlying cause that this study could not fully capture. The profound differences in personality profiles between regions can point to a deep-rooted culture that developed through historical events and human interactions. We have discussed that the personality profiles of regions could have been influenced by religious differences. However, we believe that linguistic differentiations (local dialects) and Dutch regions that were disparately hit by, for example, the Spanish flu, flood disasters, or bombing could play a role in an even broader understanding of the different personality profiles in the Netherlands. Obschonka et al. (2018) find that local coal-based industries in England and Wales predict today's psychological make-up of the particular areas, with, for example, greater levels of neuroticism, lower levels of conscientiousness, and lower life satisfaction. A challenge of the addition of such cultural and historical components is that the data, when available, are often highly aggregated and geographical boundaries have also been changing through time.

To conclude, expansion of the research foci of the residential settlement of recent graduates by including the role of personality traits contributes to a broader understanding of graduates' spatial behaviour and informs our understanding of environmental characteristics and personality differences in the Netherlands. We hope that the findings of the current study will stimulate further multidisciplinary research on geographical personality profiles and the role of psychological factors in settlement behaviour. We believe that the different assets of behavioural, economic, and social disciplines can provide insightful information on residential location and will instigate many future research questions. 


\section{References}

Abreu, M., Faggian, A., McCann, P. (2014). Migration and inter-industry mobility of UK graduates. Journal of Economic Geography, 15(2): 353-385. doi:https://doi.org/10.1093/jeg/lbt043

Abreu, M., Koster, S., Venhorst, V. (2014). Transitions and location choice: Analysing the decisions of students and recent graduates. Spatial Economic Analysis, 9(4): 349-354. doi:10.1080/17421772.2014.965552

Ahlin, L., Andersson, M., Thulin, P. (2014). Market thickness and the early labour market career of university graduates: An urban advantage? Spatial Economic Analysis, 9(4): 396-419. doi:10.1080/17421772.2014.961534

Allen, J., Belfi, B., Mommers, A. (2016). Van starter tot gevorderde: De loopbaanontwikkeling van hbo'ers in de eerste vijf jaren na afstuderen. Maastricht ROA reports no. 006. Research Centre for Education and the Labour Market.

Allen, J.P., Breugel, G.A.A. van, Coenen, J.B, Fouarge, D., Meng, C.M., Ramaekers, G.W.M., Dijk, J. van, Venhorst, V. (2009). Afgestudeerden van het hbo tijdens een crisis: Geen verloren generatie. The Hague: HBO-raad.

Allik, J., McCrae, R. (2004). Toward a geography of personality traits. Patterns of profiles across 36 cultures. Journal of Cross-Cultural Psychology, 35(1): 13-28. doi:10.1177/0022022103260382

Allik, J., Realo, A., Mottus, R., Pullmann, H., Trifonova, A., McCrae, R.R. (2009). Personality traits of Russians from the observer's perspective. European Journal of Personality, 23: 567-588. doi:10.1002/per.721

Andrews, M., Clark, K., Whittaker, W. (2011). The determinants of regional migration in Great Britain: A duration approach. Journal of the Royal Statistics Society, 174(1): 127-153. doi:https://doi.org/10.1111/j.1467-985X.2010.00656.x

Ashton, M. (2007). Individual Differences and Personality. Burlington, MA: Elsevier Academic Press.

Aybek, C., Huinink, J., Muttarak, R. (2015). Migration, spatial mobility and living arrangements: An introduction. In C. Aybek, J. Huinink, R. Muttarak (eds.), Spatial Mobility, Migration, and Living Arrangements (pp. 1-19). Heidelberg: Springer.

Ayhan, S.H., Gatskova, K., Lehmann, H. (2017). The Impact of Non-Cognitive Skills and Risk Preferences on Rural-to-Urban Migration: Evidence from Ukraine. Bonn: IZA Institute for Labor Economics.

Becker, A., Deckers, T., Dohmen, T.J., Falk, A., Kosse, F. (2012). The relationship between economic preferences and psychological personality measures. Maastricht ROA research memorandum.

Berck, P., Tano, S., Westerlund, O. (2016). Regional sorting of human capital: The choice of location among young adults in Sweden. Regional Studies, 50(5): 757-770.

doi:10.1080/00343404.2014.931935 
Bouchard, T., Loehlin, J. (2001). Genes, evolution, and personality. Behavior Genetics, 31(3): 243-273.

Busch, O., Weigert, B. (2010). Where have all the graduates gone? Internal cross-state migration of graduates in Germany 1984-2004. The Annals of Regional Science, 44(3): 559-572. doi:10.1007/s00168-008-0274-3

Canache, D., Hayes, M., Mondak, J.J., Wals, S.C. (2013). Openness, extraversion and the intention to emigrate. Journal of Research in Personality, 47(4): 351-355. doi:10.1016/j.jrp.2013.02.008

Carree, M., Kronenberg, K. (2014). Locational choices and the costs of distance: Empirical evidence for Dutch graduates. Spatial Economic Analysis, 9(4): 420-435. doi:10.1080/17421772.2014.961535

Corcoran, J., Faggian, A. (2017). Graduate migration and regional development: An international perspective. In J. Corcoran, A. Faggian (eds.), Graduate Migration and Regional Development (pp. 1-10). Cheltenham: Edward Elgar Publishing Limited.

Cornips, L. (2018). Social meanings of the north-south divides in the Netherlands and Limburg and their linkage to standard Dutch and dialect varieties. In B.E. Evans, E. Benson, J. Stanford (eds.), Language Regard. Methods, Variation and Change. (pp. 96-117). Cambridge: Cambridge University Press.

Cornips, L., Knotter, A. (2018). Limburg (the Netherlands): Territory, history, language and identity. In H. Christen, P. Gilles, C. Purschke (eds.), Räume, Grenzen, Übergänge. Akten des 5. Kongresses der Internationalen Gesellschaft für Dialektologie des Deutschen (IGDD) (pp. 7192). Stuttgart: Steiner.

Costa, P., McCrae, R. (2008). The revised NEO personality inventory (NEO-PI-R). In G. Boyle, G. Matthews, D. Saklofske (eds.), The SAGE Handbook of Personality Theory and Assessment (pp. 179-198). Thousand Oaks: SAGE Publications.

Czaika, M. (2018). High-Skilled Migration: Drivers and Policies. Oxford: OUP Oxford.

DaVanzo, J., Morrison, P. (1981). Return and other sequences of migration in the United States. Demography, 18(1): 85-101. doi:10.2307/2061051

Faggian, A., McCann, P. (2009a). Universities, agglomerations and graduate human capital mobility. Tijdschrift voor Economische en Sociale Geografie, 100(2): 210-223. doi:10.1111/j.14679663.2009.00530.x

Faggian, A., McCann, P. (2009b). Human capital, graduate migration and innovation in British regions. Cambridge Journal of Economics, 33(2): 317-333. doi:10.1093/cje/ben042

Faggian, A., McCann, P., Sheppard, S. (2007a). Human capital, higher education and graduate migration: An analysis of Scottish and Welsh students. Urban Studies, 44(13): 2511-2528. doi:https://doi.org/10.1080/00420980701667177 
Faggian, A., McCann, P., Sheppard, S. (2007b). Some evidence that women are more mobile than men: Gender differences in UK graduate migration behaviour. Journal of Regional Science, 47(3): 517-539. doi:10.1111/j.1467-9787.2007.00518.x

Fielding, A. (1992). Migration and social mobility: South East England as an escalator region. Regional Studies, 26(1): 1-15. doi:10.1080/00343409212331346741

Fouarge, D., Özer, M., Seegers, P. (2019). Personality traits, migration intentions, and cultural distance. Papers in Regional Science. doi:https://doi.org/10.1111/pirs.12468

Garretsen, H., Stoker, J., Soudis, D., Martin, R., Rentfrow, J. (2019). The relevance of personality traits for urban economic growth: Making space for psychological factors. Journal of Economic Geography(19): 541-565.

Glaeser, E.L., Kolko, J., Saiz, A. (2001). Consumer city. Journal of Economic Geography, 1(1): 27-50. doi:https://doi.org/10.1093/jeg/1.1.27

Gosling, S., Rentfrow, J., Swann, W. (2003). Very brief measure of the big-five personality domains. Journal of Research in Personality, 37: 504-528. doi:10.1016/S0092-6566(03)00046-1

Greenwood, M. (1985). Human migration: Theory, models and empirical studies. Journal of Regional Science, 25: 521-544.

Haapanen, M., Tervo, H. (2012). Migration of the highly educated: Evidence from residence spells of university graduates. Journal of Regional Science, 52(4): 587-605. doi:10.1111/j.14679787.2011.00745.x

Haussen, T., Uebelmesser, S. (2015). No place like home? Graduate migration in Germany. CESIFO Working paper no. 5524: 1-27.

Hofstede, G., McCrae, R.R. (2004). Personality and culture revisited: Linking traits and dimensions of culture. 38(1): 52-88. doi:10.1177/1069397103259443

Hooijen, I., Meng, C., Reinold, J., Siegel, M. (2017). Competition for talent: Retaining graduates in the Euregio Meuse-Rhine. European Planning Studies, 25(12): 2212-2231. doi:https://doi.org/10.1080/09654313.2017.1354976

Imeraj, L., Willaert, D., Finney, N., Gadeyne, S. (2017). Cities' attraction and retention of graduates: A more-than-economic approach. Regional Studies. doi:10.1080/00343404.2017.1362499

Jokela, M. (2009). Personality predicts migration within and between U.S. states. Journal of Research in Personality, 43: 79-83. doi:10.1016/j.jrp.2008.09.005

Jokela, M. (2014). Personality and the realization of migration desires. In P. Rentfrow (ed.), Geographical Psychology. Exploring the Interaction of Environment and Behavior (pp. 71-87). Washington DC: American Psychological Association. 
Jokela, M., Bleidorn, W., Lamb, M.E., Gosling, S.D., Rentfrow, P.J. (2015). Geographically varying associations between personality and life satisfaction in the London metropolitan area. Proceedings of the National Academy of Sciences, USA, 112: 725-730. doi:10.1073/pnas.1415800112

Jokela, M., Elovainio, M., Kivimäki, M., Keltikangas-Järvinen, L. (2008). Temperament and migration patterns in Finland. Psychological Science, 19(9): 831-837. doi:10.1111/j.14679280.2008.02164.x

Kiesraad. (2017). Uitslagen Tweede Kamerverkiezing 2017. Retrieved from Kiesraad: https://www.kiesraad.nl/verkiezingen/adviezen-enpublicaties/publicaties/2017/uitslagen/uitslagen-tweede-kamerverkiezing-2017/uitslagentweede-kamerverkiezing-2017

King, R., Findley, A. (2012). Student migration. In M. Martiniello, J. Rath (eds.), An Introduction to International Migration Studies: European Perspectives (IMISCOE Textbooks). Amsterdam: Amsterdam University Press.

King, R., Raghuram, P. (2013). International student migration: Mapping the field and new research agendas. Population, Space and Place, 19(2): 127-137. doi:10.1002/psp.1746

Kondo, K. (2016). Hot and cold spot analysis using Stata. The Stata Journal, 16(3): 613-631.

Krabel, S., Flöther, C. (2014). Here today, gone tomorrow? Regional labour mobility of German university graduates. Regional Studies, 48(10): 1609-1627. doi:10.1080/00343404.2012.739282

Lammarino, S., Marinelli, E. (2015). Education-job (mis)match and interregional migration: Italian university graduates' transition to work. Regional Studies, 49(5): 866-882. doi:10.1080/00343404.2014.965135

Lang, F., John, O., Lüdtke, J., Schupp, J., Wagner, G. (2011). Short assessment of the big five: Robust across survey methods except telephone interviewing. Behavior Research Methods, 43: 548567. doi:10.3758/s13428-011-0066-z

Lee, N. (2017). Psychology and the geography of innovation. Economic Geography, 93(2): 106-130. doi:10.1080/00130095.2016.1249845

Marinelli, E. (2013). Sub-national graduate mobility and knowledge flows: An exploratory analysis of onward- and return-migrants in Italy. Regional Studies, 47(10): 1618-1633. doi:10.1080/00343404.2012.709608

McCrae, R.R., Costa, P.T. (2003). Personality in Adulthood: A Five-Factor Theory Perspective (2nd. ed.). New York: The Guilford Press.

McCrae, R., Costa, P.J., Terracciano, A., Parker, W., Mills, C., De Fruyt, F., Mervielde, I. (2002). Personality trait development from age 12 to age 18: Longitudinal, cross-sectional, and cross-cultural analyses. Journal of Personality and Social Psychology, 83(6): 1456-1468. doi:10.1037//0022-3514.83.6.1456 
McCrae, R.R., Yik, M.S., Trapnell, P.D., Bond, M.H., Paulhus, D.L. (1998). Interpreting personality profiles across cultures: Bilingual, acculturation, and peer rating studies of Chinese undergraduates. Journal of Personality and Social Psychology, 74(4): 1041-1055. doi:http://dx.doi.org/10.1037/0022-3514.74.4.1041

Motyl, M., Iyer, R., Oishi, S., Trawalter, S., Nosek, B. (2014). How ideological migration geographically segregates groups. Journal of Experimental Social Psychology, 51: 1-14.

Murray, G.G., Judd, F., Jackson, H., Fraser, C., Komiti, A., Hodgins, G., Pattison, P., Humphreys, J., Robins, G. (2005). The five factor model and accessibility/remoteness: Novel evidence for person-environment interaction. Personality and Individual Differences, 39: 715-725. doi:10.1016/j.paid.2005.02.007

Nuffic. (2017). Higher education. Retrieved January 10, 2018, from Nuffic, The Dutch Organisation for Internationalisation in Education: https://www.nuffic.nl/en/study-and-work-inholland/dutch-education-system/higher-education

Obschonka, M., Schmitt-Rodermund, E., Silbereisen, R.K., Gosling, S.D., Potter, J. (2013). The regional distribution and correlates of an entrepreneurship-prone personality profile in the United States, Germany, and the United Kingdom: A socioecological perspective. Journal of Personality and Social Psychology, 105: 104-122. doi:10.1037/a0032275

Obschonka, M., Stuetzer, M., Rentfrow, P., Shaw-Taylor, L., Satchell, M., Silbereisen, R.K., Potter, J., Gosling, S. (2018). In the shadow of coal: How large-scale industries contributed to presentday regional differences in personality and well-being. Journal of Personality and Social Psychology, 115(5): 903-927. doi:http://dx.doi.org/10.1037/pspp0000175

Oishi, S., Talhelm, T., Lee, M. (2015). Personality and geography: Introverts prefer mountains. Journal of Research in Personality, 58: 55-68. doi:10.1016/j.jrp.2015.07.001

Park, N., Peterson, C. (2014). The city where we live matters: The psychology of cities. In P.J. Rentfrow (ed.), Geographical Psychology. Exploring the Interaction of Environment and Behavior. (pp. 179-193). Washington DC: American Psychological Association.

Pennebaker, J., Rime, B., Blankenship, V.E. (1996). Stereotypes of emotional expressiveness of northerners and southerners: A cross-cultural test of Montesquieu's hypotheses. Journal of Personality and Social Psychology, 70(2): 372-80.

Putnam, R., Campbell, D. (2012). American Grace: How Religion Divides and Unites Us. New York: Simon \& Schuster.

Rammstedt, B., John, O. (2007). Measuring personality in one minute or less: A 10-item short version of the big five inventory in English and German. Journal of Research in Personality, 41: 203212. doi:10.1016/j.jrp.2006.02.001

Rentfrow, P.J. (2010). Statewide differences in personality. Toward a psychological geography of the United States. American Psychologist, 65(6): 548-558. doi:10.1037/a0018194 
Rentfrow, P.J. (ed.) (2014). Geographical Psychology. Exploring the Interaction of Environment and Behavior. Washington DC: American Psychological Association.

Rentfrow, P.J., Gosling, S.D., Jokela, M., Stillwell, D.J., Kosinski, M., Potter, J. (2013). Divided we stand: Three psychological regions of the United States and their political, economic, social, and health correlates. Journal of Personality and Social Psychology, 105(6): 996-1012. doi:10.1037/a0034434

Rentfrow, P., Gosling, S.D., Potter, J. (2008). A theory of the emergence, persistence, and expression of geographic variation in psychological characteristics. Perspectives on Psychological Science, 3(5): 339-369. doi:http://www.jstor.org/stable/40212258

Rentfrow, P., Jokela, M. (2016). Geographical psychology: The spatial organization of psychological phenomena. Current Directions in Psychological Science, 25(6): 393-398. doi:10.1177/0963721416658446

Rentfrow, P.J., Jokela, M., Lamb, M.E. (2015). Regional personality differences in Great Britain. PLOS One, 10(3): 1-20. doi:doi:10.1371/journal

Schaller, M., Murray, D.R. (2008). Pathogens, personality and culture: Disease prevalence predicts worldwide variability in sociosexuality, extraversion, and openness to experience. Journal of Personality and Social Psychology, 95: 212-221. doi:doi:10.1037/0022-3514.95.1.212

Schmeets, H. (2016). De religieuze kaart van Nederland, 2010-2015. The Hague: Centraal Bureau voor de Statistiek.

Sjaastad, L. (1962). The costs and returns of human migration. Journal of Political Economy, 70(5): 80-93.

Statistics Netherlands. (2016). Transport and Mobility 2016. The Hague: Statistics Netherlands.

Statistics Netherlands. (2019). CBS. Retrieved from Bevolking; leeftijd, migratieachtergrond, geslacht en regio, 1 januari: https://opendata.cbs.nl/statline/\#/CBS/nl/dataset/37713/table?ts=1565099973107

Stuetzer, M., Audretsch, D., Obschonka, M., Gosling, S., P, J.R., Potter, J. (2018). Entrepreneurship culture, knowledge spillovers and the growth of regions. Regional Studies, 52(5): 608-618. doi:?https://doi.org/10.1080/00343404.2017.1294251

Teichert, C., Niebuhr, A., Otto, A., Rossen, A. (2018). Graduate migration in Germany new evidence from an event history analysis. IAB-Discussion Paper.

Train, K. (2003). Discrete Choice Methods with Simulation. Cambridge: University Press Cambridge.

van Elk, M., Rutjensa, B., van Harreveld, F. (2017). Why are Protestants more prosocial than Catholics? A comparative study among orthodox Dutch believers. The International Journal for the Psychology of Religion, 27(1): 65-81. doi:http://dx.doi.org/10.1080/10508619.2017.1245023 
Venhorst, V. (2012). Window on the Netherlands. Graduate migration and regional familiarity. Tijdschrift voor Economische en Sociale Geografie, 104(1): 109-119. doi:10.1111/tesg.12000

Venhorst, V., Cörvers, F. (2018). Entry into working life: Internal migration and the job match quality of higher educated graduates. Journal of Regional Science, 58: 116-140. doi:10.1111/jors.12347

Venhorst, V., Van Dijk, J., Van Wissen, L. (2010). Do the best graduates leave the peripheral areas of the Netherlands? 101(5): 521-537. doi:10.1111/j.1467-9663.2010.00629.x

Venhorst, V., Van Dijk, J., Van Wissen, L. (2011). An analysis of trends in spatial mobility of Dutch graduates. Spatial Economic Analysis, 6(1): 1742-1780. doi:10.1080/17421772.2010.540033

Vereniging Hogescholen. (2018). Kennisbank Feiten en Cijfers. Retrieved January 10, 2018, from Vereniging Hogescholen: http://www.vereniginghogescholen.nl/kennisbank/feiten-encijfers/artikelen/feiten-en-cijfers-qlikview

Vukasović, T., Bratko, D. (2015). Heritability of personality: A meta-analysis of behavior genetic studies. Psychological Bulletin, 141(4): 769-785. doi:10.1037/bul0000017.supp 
Appendix 1a: Composition of the categorical variables from the PCA

\begin{tabular}{|c|c|}
\hline Variable & Coefficient \\
\hline \multicolumn{2}{|l|}{ Demographic development } \\
\hline Urbanization & -0.03 \\
\hline Population development & 0.51 \\
\hline Population density & 0.47 \\
\hline Net migration & 0.50 \\
\hline Elderly & -0.31 \\
\hline One-person household & 0.41 \\
\hline \multicolumn{2}{|l|}{ Economic viability } \\
\hline Entrepreneurs & 0.69 \\
\hline Labour market participation & 0.20 \\
\hline Human Capital & 0.69 \\
\hline \multicolumn{2}{|l|}{ Physical green space } \\
\hline Green space & 0.71 \\
\hline Cows & 0.71 \\
\hline Political populism & $*$ \\
\hline \multicolumn{2}{|l|}{ Heath } \\
\hline Diabetes meds & 0.57 \\
\hline Heart meds & 0.59 \\
\hline Nerves meds & 0.55 \\
\hline Mortality rates & -0.16 \\
\hline \multicolumn{2}{|l|}{ Sociocultural attractiveness } \\
\hline Distance to facilities & -0.34 \\
\hline Number of bars, restaurants & 0.49 \\
\hline Number of museums & 0.48 \\
\hline Number of cinemas & 0.45 \\
\hline Cultural diversity & 0.45 \\
\hline \multicolumn{2}{|l|}{ Crime } \\
\hline Thefts & 0.71 \\
\hline Firearm crimes & 0.71 \\
\hline \multicolumn{2}{|l|}{ Religiosity } \\
\hline Church visits & 0.58 \\
\hline No church visits & -0.06 \\
\hline Catholic & -0.11 \\
\hline Protestants & 0.43 \\
\hline Islam & -0.11 \\
\hline Religion different & 0.37 \\
\hline SGP* votes & 0.56 \\
\hline
\end{tabular}

* A single normalized variable

* Reformed Political Party 
Appendix 1b: Description of environmental characteristics at the municipality level

\begin{tabular}{|c|c|c|}
\hline Variable & Description* & Data source \\
\hline \multicolumn{3}{|l|}{ Demographic growth } \\
\hline Urbanization & $\begin{array}{l}\text { The urbanization level is divided into } 5 \text { categories. } \\
\text { Dutch areas with more than 2,500 objects per square } \\
\text { kilometre are categorized as highly urbanized. Areas } \\
\text { with fewer than } 500 \text { objects per square kilometre are } \\
\text { considered rural (Statistics Netherlands, 2019) }\end{array}$ & $\begin{array}{l}\text { Statistics } \\
\text { Netherlands } \\
\left(2015^{* *}\right)\end{array}$ \\
\hline $\begin{array}{l}\text { Population } \\
\text { development }\end{array}$ & $\begin{array}{l}\text { Population development by birth, death, and } \\
\text { migration }\end{array}$ & $\begin{array}{l}\text { Statistics } \\
\text { Netherlands }\end{array}$ \\
\hline Population density & $\begin{array}{l}\text { Number of inhabitants per square meter, calculated } \\
\text { by dividing the population by the land surface } \\
\text { (rounded to the nearest number) }\end{array}$ & $\begin{array}{l}\text { Statistics } \\
\text { Netherlands } \\
\text { (2015) }\end{array}$ \\
\hline Net migration & $\begin{array}{l}\text { Number of persons who moved between Dutch } \\
\text { municipalities }\end{array}$ & $\begin{array}{l}\text { Statistics } \\
\text { Netherlands }\end{array}$ \\
\hline Elderly & $\%$ of people aged over 65 & $\begin{array}{l}\text { Statistics } \\
\text { Netherlands }\end{array}$ \\
\hline $1 \mathrm{HH}$ composition & Number of households with one person & $\begin{array}{l}\text { Statistics } \\
\text { Netherlands }\end{array}$ \\
\hline \multicolumn{3}{|l|}{ Economic viability } \\
\hline Entrepreneurs & Number of entrepreneurs $(* 1,000)$ & $\begin{array}{l}\text { Statistics } \\
\text { Netherlands }\end{array}$ \\
\hline LM participation & Percentage employed in the labour force & $\begin{array}{l}\text { Statistics } \\
\text { Netherlands }\end{array}$ \\
\hline Human capital & $\begin{array}{l}\text { Percentage of inhabitants with a higher education } \\
\text { degree (HBO, universities of applied sciences, or WO, } \\
\text { research universities) }\end{array}$ & $\begin{array}{l}\text { Statistics } \\
\text { Netherlands }\end{array}$ \\
\hline \multicolumn{3}{|l|}{ Physical green space } \\
\hline Green space & Area dedicated to green space (in hectares) & $\begin{array}{l}\text { Statistics } \\
\text { Netherlands }\end{array}$ \\
\hline Cows & Number of cows & $\begin{array}{l}\text { Statistics } \\
\text { Netherlands }\end{array}$ \\
\hline \multicolumn{3}{|l|}{ Political populism } \\
\hline PVV & $\begin{array}{l}\text { Percentage of votes for the Party for Freedom } \\
\text { (nationalism) in } 2017 \text { for the election of the Dutch } \\
\text { House of Representatives }\end{array}$ & $\begin{array}{l}\text { Central } \\
\text { electoral } \\
\text { committee } \\
\text { (Kiesraad, } \\
\text { 2017) }\end{array}$ \\
\hline \multicolumn{3}{|l|}{ Health } \\
\hline Diabetes & $\begin{array}{l}\text { Percentage of inhabitants on medication for } \\
\text { diabetes }\end{array}$ & $\begin{array}{l}\text { Statistics } \\
\text { Netherlands }\end{array}$ \\
\hline Heart & $\begin{array}{l}\text { Percentage of inhabitants on medication for } \\
\text { cardiovascular disease }\end{array}$ & $\begin{array}{l}\text { Statistics } \\
\text { Netherlands }\end{array}$ \\
\hline Nerves & $\begin{array}{l}\text { Percentage of inhabitants on medication for a } \\
\text { neurological condition }\end{array}$ & $\begin{array}{l}\text { Statistics } \\
\text { Netherlands }\end{array}$ \\
\hline Mortality & Number of deaths & $\begin{array}{l}\text { Statistics } \\
\text { Netherlands }\end{array}$ \\
\hline
\end{tabular}




\begin{tabular}{|c|c|c|}
\hline Variable & Description* & Data source \\
\hline \multicolumn{3}{|l|}{ Sociocultural attractiveness } \\
\hline Facilities & $\begin{array}{l}\text { Distance to facilities, such as to a general } \\
\text { practitioner or primary school within a radius of } 5 \\
\text { km from one's home (per } 100 \text { metres) }\end{array}$ & $\begin{array}{l}\text { Statistics } \\
\text { Netherlands }\end{array}$ \\
\hline Bars, restaurants & Number of bars and restaurants & $\begin{array}{l}\text { Statistics } \\
\text { Netherlands }\end{array}$ \\
\hline Museums & Number of museums & $\begin{array}{l}\text { Statistics } \\
\text { Netherlands }\end{array}$ \\
\hline Cinemas & Number of cinemas & $\begin{array}{l}\text { Statistics } \\
\text { Netherlands }\end{array}$ \\
\hline Cultural diversity & $\begin{array}{l}\text { Calculated by dividing the number of persons who } \\
\text { have at least one parent who was not born in the } \\
\text { Netherlands, scaled by the entire population of the } \\
\text { Local Administrative Unit II }\end{array}$ & $\begin{array}{l}\text { Statistics } \\
\text { Netherlands }\end{array}$ \\
\hline \multicolumn{3}{|l|}{ Crime level } \\
\hline Thefts & Number of thefts (rounded to the nearest 5) & $\begin{array}{l}\text { Statistics } \\
\text { Netherlands }\end{array}$ \\
\hline Firearm crimes & $\begin{array}{l}\text { Number of registered firearm crime suspects } \\
\text { (rounded to the nearest 5) }\end{array}$ & $\begin{array}{l}\text { Statistics } \\
\text { Netherlands }\end{array}$ \\
\hline \multicolumn{3}{|l|}{ Religiosity } \\
\hline Church visits & Percentage attending weekly church services & $\begin{array}{l}\text { Statistics } \\
\text { Netherlands }\end{array}$ \\
\hline No church visits & Percentage not attending weekly church services & $\begin{array}{l}\text { Statistics } \\
\text { Netherlands }\end{array}$ \\
\hline Catholic & A dummy if the Catholic religion is dominant & $\begin{array}{l}\text { Statistics } \\
\text { Netherlands }\end{array}$ \\
\hline Protestants & A dummy if the Protestant religion is dominant & $\begin{array}{l}\text { Statistics } \\
\text { Netherlands }\end{array}$ \\
\hline Islam & $\begin{array}{l}\text { Percentage following the religion of Islam within the } \\
\text { municipality }\end{array}$ & $\begin{array}{l}\text { Statistics } \\
\text { Netherlands }\end{array}$ \\
\hline Religion different & $\begin{array}{l}\text { Percentage of those following other religions within } \\
\text { the municipality }\end{array}$ & $\begin{array}{l}\text { Statistics } \\
\text { Netherlands }\end{array}$ \\
\hline SGP & $\begin{array}{l}\text { Percentage of votes for the Reformed Political Party } \\
\text { in } 2017 \text { for the election of the Dutch House of } \\
\text { Representatives (Christian conservative) }\end{array}$ & $\begin{array}{l}\text { Central } \\
\text { electoral } \\
\text { committee } \\
\text { (Kiesraad, } \\
\text { 2017) }\end{array}$ \\
\hline
\end{tabular}

${ }^{*}$ The unit of analysis is at the municipality level (*Local Administrative Unit II), unless stated otherwise.

**Data from Statistic Netherlands are from 2015, unless stated otherwise. 
Appendix 2: Different specifications of the distance matrix, at 25, 50, 75, and 100 kilometres, with maps based on the place of residence 1.5 years after graduation

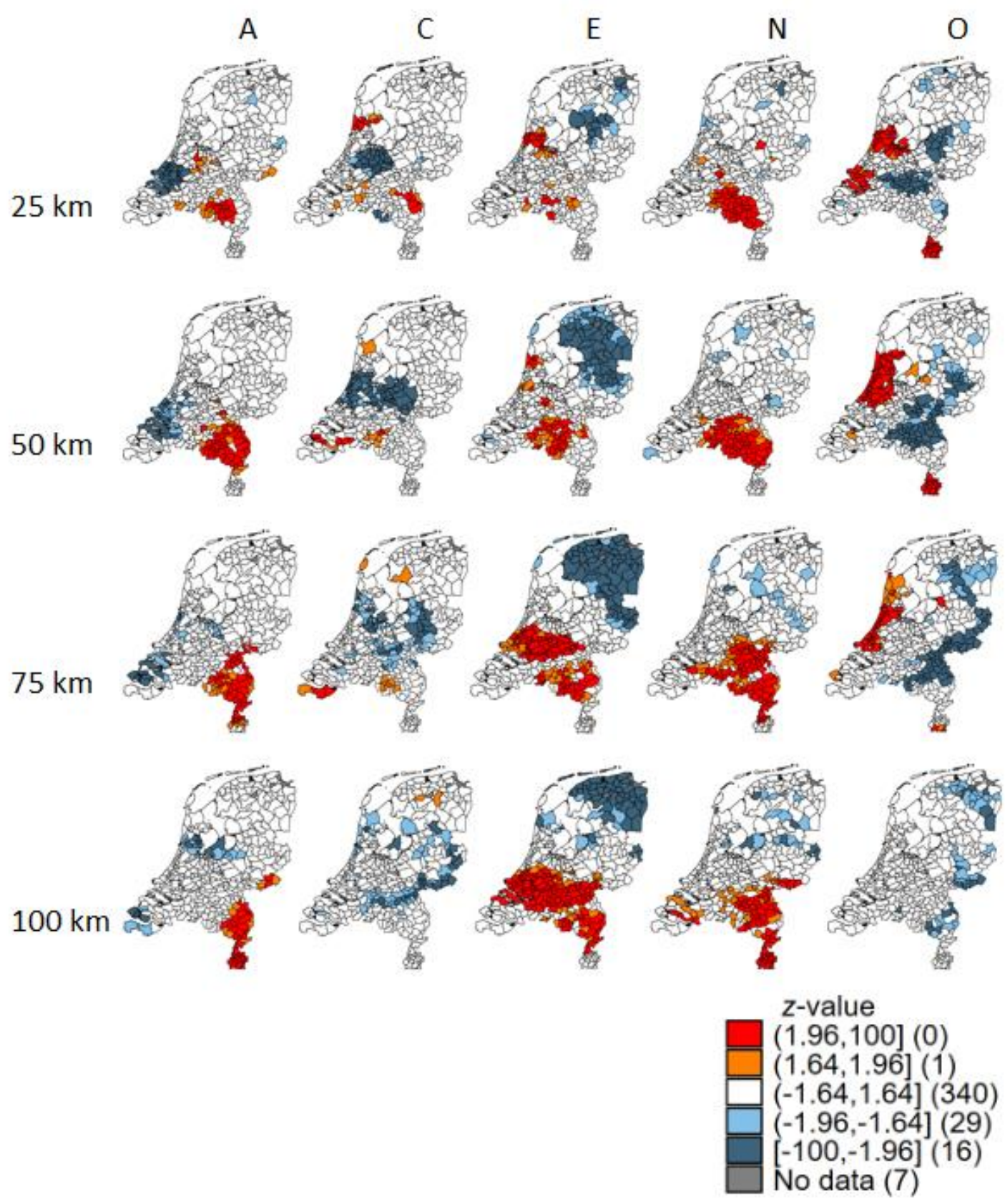

Note: In this figure, A represents agreeableness, $\mathrm{C}$ conscientiousness, E extraversion, $\mathrm{N}$ neuroticism, and $\mathrm{O}$ openness to experience. 
Appendix 3: The relationship between personality traits and the underlying components of each environmental factor, after normalization and the grouping of high and low personality traits

\begin{tabular}{|c|c|c|c|c|c|c|}
\hline & A & $\mathrm{C}$ & $\mathbf{E}$ & $\mathbf{N}$ & 0 & $\begin{array}{l}\text { Sample } \\
\text { size }\end{array}$ \\
\hline \multicolumn{7}{|l|}{ Demographic development } \\
\hline Urbanization & $0.03 * *$ & $0.06 * * *$ & & & $-0.05 * * *$ & 6718 \\
\hline Population development & & $-0.06 * * *$ & & & $0.05^{* * *}$ & 6718 \\
\hline Population density & & & & & & 6718 \\
\hline Net migration & & & & & & 6718 \\
\hline Elderly & & $0.06 * * *$ & & $-0.02 *$ & & 6718 \\
\hline One person household & & $-0.06 * * *$ & & $0.03 * * *$ & $0.04 * * *$ & 6718 \\
\hline \multicolumn{7}{|l|}{ Economic viability } \\
\hline Entrepreneurs & & $-0.06 * * *$ & & & $0.05 * * *$ & 6718 \\
\hline LM participation & $0.02 *$ & & & & $-0.02 * *$ & 6718 \\
\hline Human Capital & $0.02 *$ & $-0.06 * * *$ & & $0.04 * * *$ & $0.03 * *$ & 6657 \\
\hline \multicolumn{7}{|l|}{ Physical green space } \\
\hline Green space & & & & & & 3761 \\
\hline Cows & & & & & & 6718 \\
\hline \multicolumn{7}{|l|}{ Political populism } \\
\hline PVV votes & & $0.05^{* * *}$ & & & & 6718 \\
\hline \multicolumn{7}{|l|}{ Health } \\
\hline Diabetes meds & $-0.04 * *$ & $0.02 *$ & $-0.03 * *$ & $-0.02 *$ & $0.02 * *$ & 6718 \\
\hline Heart meds & $-0.02 *$ & $0.05^{* * *}$ & & $-0.03 * * *$ & $-0.02 *$ & 6718 \\
\hline Nerves meds & $-0.03 * *$ & & & & & 6718 \\
\hline Mortality rates & & & & & & 6718 \\
\hline \multicolumn{7}{|l|}{ Sociocultural attractiveness } \\
\hline Distance to facilities & & $0.05^{* * *}$ & & & $-0.04 * * *$ & 6718 \\
\hline Number of bars, restaurants & & & & & & 6718 \\
\hline Number of museums & & $-0.07 * * *$ & & & $0.04 * * *$ & 6718 \\
\hline Number of cinemas & & $-0.07 * * *$ & & $0.03 * *$ & $0.04 * * *$ & 6718 \\
\hline Cultural diversity & & & & & & 6718 \\
\hline \multicolumn{7}{|l|}{ Crime level } \\
\hline Thefts & & & & & & 6665 \\
\hline Firearm crimes & & $-0.05 * * *$ & & & $0.05^{* * *}$ & 6718 \\
\hline \multicolumn{7}{|l|}{ Religiosity } \\
\hline Church visits & & & & & $-0.04 * * *$ & 6661 \\
\hline No church visits & & $-0.04 * * *$ & & & & 6718 \\
\hline Catholic & & $0.03 * *$ & & & & 6718 \\
\hline Protestants & & $0.02 * *$ & $-0.03 * *$ & & $-0.03 * * *$ & 6718 \\
\hline Islam & & $-0.05 * * *$ & $-0.02 *$ & & $0.05^{* * *}$ & 6661 \\
\hline Religion different & & $-0.04 * * *$ & $-0.03 * *$ & & & 6661 \\
\hline SGP votes & & & & & $-0.03 * * *$ & 6718 \\
\hline
\end{tabular}


Note: In this figure, A represents agreeableness, $\mathrm{C}$ conscientiousness, E extraversion, $\mathrm{N}$ neuroticism, and $\mathrm{O}$ openness to experience.

${ }^{* * *} p<0.01,{ }^{* *} \mathrm{p}<0.05,{ }^{*} \mathrm{p}<0$ 
Appendix 4: Results for the discrete choice model with the full list of factors, the impact of the environmental variables, and the interaction effects with the Big Five personality traits (A, C, E, N, and O)

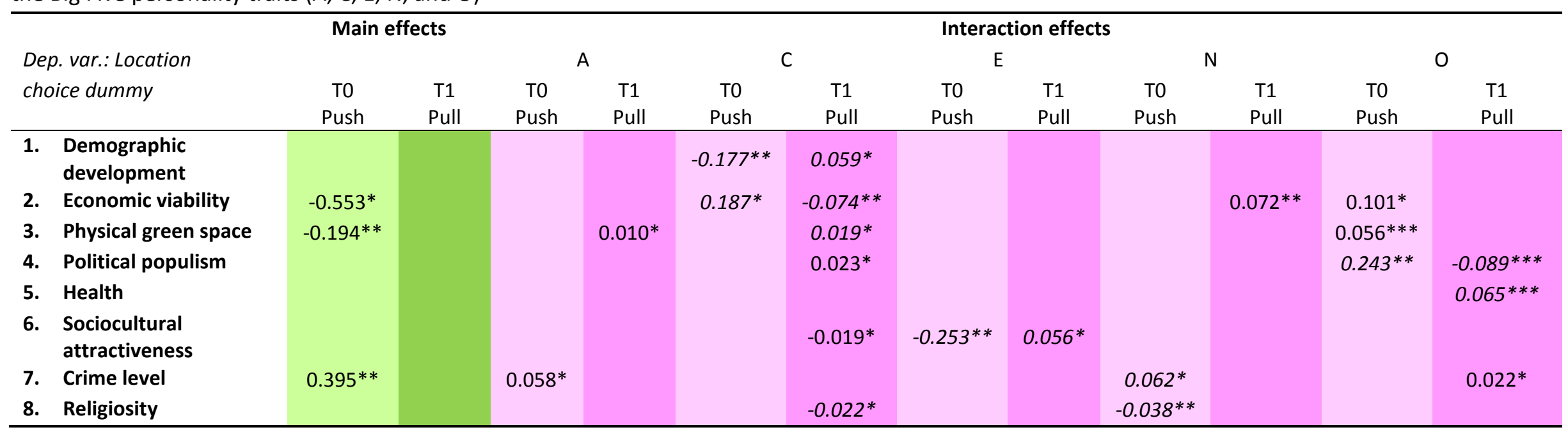

Note: The variables represent distance, distance squared, prior mobility, and the main effects of the Big Five traits and personal characteristics (including age, age squared, gender, household situation, average grade, and whether seeking a job). For the interaction variables, we report the effects for high scorers (four indicates agreement, five strong agreement). We use italics to denote that the effect is only present among low scorers (one indicates strong disagreement, two disagreement). The numbers are given as the coefficients of the main model. The base category is set to a value of three.

$* * * p<0.01, * * p<0.05, * p<0.1$ 
Appendix 5: Results of the discrete choice model, the impact of environmental variables, and the interaction effects with the Big Five personality traits on a continuous scale $(A, C, E, N$, and $O)$

\begin{tabular}{|c|c|c|c|c|c|c|c|c|c|c|c|c|}
\hline \multirow{3}{*}{$\begin{array}{l}\text { Dep. var.: Location } \\
\text { choice dummy }\end{array}$} & \multicolumn{2}{|c|}{ Main effects } & \multicolumn{10}{|c|}{ Interaction effects } \\
\hline & \multirow[b]{2}{*}{$\begin{array}{c}\text { T0 } \\
\text { Push }\end{array}$} & \multirow[b]{2}{*}{$\begin{array}{c}\text { T1 } \\
\text { Pull }\end{array}$} & \multicolumn{2}{|c|}{$A$} & \multicolumn{2}{|c|}{$\mathrm{C}$} & \multicolumn{2}{|c|}{$E$} & \multicolumn{2}{|c|}{$\mathrm{N}$} & \multicolumn{2}{|c|}{0} \\
\hline & & & $\begin{array}{c}\text { T0 } \\
\text { Push }\end{array}$ & $\begin{array}{c}\text { T1 } \\
\text { Pull }\end{array}$ & $\begin{array}{c}\text { T0 } \\
\text { Push }\end{array}$ & $\begin{array}{c}\text { T1 } \\
\text { Pull }\end{array}$ & $\begin{array}{c}\text { T0 } \\
\text { Push }\end{array}$ & $\begin{array}{c}\text { T1 } \\
\text { Pull } \\
\end{array}$ & $\begin{array}{c}\text { T0 } \\
\text { Push }\end{array}$ & $\begin{array}{c}\text { T1 } \\
\text { Pull }\end{array}$ & $\begin{array}{c}\text { T0 } \\
\text { Push }\end{array}$ & $\begin{array}{c}\text { T1 } \\
\text { Pull }\end{array}$ \\
\hline $\begin{array}{l}\text { 1. Economic viability } \\
\text { 2. Physical green space }\end{array}$ & $-0.559 * *$ & $0.094^{*}$ & & & & $-0.004^{*}$ & & & & & & \\
\hline 3. Political populism & & & & & & $0.019 * * *$ & & & & & & \\
\hline 4. Religiosity & $-0.324 *$ & $0.233 * * *$ & & & & & & $\begin{array}{c}- \\
0.010^{*}\end{array}$ & $0.015^{*}$ & & & \\
\hline
\end{tabular}

Note: The variables represent distance, distance squared, prior mobility, and the main effects of the Big Five and personal characteristics (including age, age squared, gender, household situation, average grade, and whether seeking a job). For the interaction variables, we report the effects of the continuous Big Five personality traits.

$* * * p<0.01, * * p<0.05, * p<0.1$ 
Appendix 6.1: Pull effects on location choice (location choice dummy) and the impact of environmental variables, with additional environmental effects due to interaction with individual Big Five personality traits $(A, C, E, N$, and $O$ ), if one model is estimated per personality trait (with the results presented together)

\begin{tabular}{|c|c|c|c|c|c|c|c|c|c|c|c|c|}
\hline \multirow{3}{*}{\multicolumn{2}{|c|}{ Environmental variables }} & \multirow{3}{*}{$\begin{array}{c}\text { Main } \\
\text { push effects }\end{array}$} & \multicolumn{10}{|c|}{ Interaction effects with the Big Five personality traits } \\
\hline & & & \multicolumn{2}{|c|}{$A$} & \multicolumn{2}{|c|}{$\mathrm{C}$} & \multicolumn{2}{|c|}{$\mathrm{E}$} & \multicolumn{2}{|c|}{$\mathrm{N}$} & \multicolumn{2}{|c|}{$\mathrm{O}$} \\
\hline & & & Low & High & Low & High & Low & High & Low & High & Low & High \\
\hline 1. & Economic viability & - & & & & & & & & & & \\
\hline 2. & Physical green space & & & & & & & & & & 00.069* & $0.038 * *$ \\
\hline 3. & Political populism & & & & & & & & & & $0.141 *$ & \\
\hline 4. & Religiosity & & & & & & & & $-0.027^{*}$ & & & \\
\hline
\end{tabular}

Note: In this figure, A represents agreeableness, C conscientiousness, E extraversion, $\mathrm{N}$ neuroticism, and O openness to experience. We control for distance, distance squared, prior mobility, and the main effects of the Big Five and personal characteristics (including age, age squared, gender, household situation, average grade, and whether seeking a job). For the interaction variables, we report the effects for high scorers (four indicates agreement, and five strong agreement) and for low scorers (one indicates strong disagreement, and two disagreement). The base category is set to a value of three. The numbers represent the estimated coefficients of the main model. Mind that positive or negative effects can be based on either high or low scorers on personality traits. The main effects are only reported in one direction, since they differ slightly by model.

$* * * p<0.01, * * p<0.05, * p<0.1$ 
Appendix 6.2: Push effects on location choice (a location choice dummy) and the impact of environmental variables, with additional environmental effects due to interaction with individual Big Five personality traits $(A, C, E, N$, and $O$ ), if one model is estimated per personality trait (with all the results presented together)

\begin{tabular}{|c|c|c|c|c|c|c|c|c|c|c|c|c|}
\hline \multirow{3}{*}{\multicolumn{2}{|c|}{ Environmental variables }} & \multirow{3}{*}{$\begin{array}{c}\text { Main } \\
\text { push effects }\end{array}$} & \multicolumn{10}{|c|}{ Interaction effects with Big Five personality traits } \\
\hline & & & \multicolumn{2}{|c|}{ A } & \multicolumn{2}{|r|}{$\mathrm{C}$} & \multicolumn{2}{|c|}{$\mathrm{E}$} & \multicolumn{2}{|c|}{$\mathrm{N}$} & \multicolumn{2}{|c|}{0} \\
\hline & & & Low & High & Low & High & Low & High & Low & High & Low & High \\
\hline 1. & Economic viability & + & & & & $-0.010 * *$ & & & & & & \\
\hline 2. & Physical green space & & & & & & & & & $-0.012 * *$ & $-0.015^{*}$ & \\
\hline 3. & Political populism & & & & $-0.037 * *$ & & & & & & & \\
\hline 4. & Religiosity & + & & & $-0.020^{*}$ & & & $-0.015^{*}$ & & & & \\
\hline
\end{tabular}

Note: In this figure, A represents agreeableness, C conscientiousness, E extraversion, $\mathrm{N}$ neuroticism, and O openness to experience. We control for distance, distance squared, prior mobility, and the main effects of the Big Five and personal characteristics (including age, age squared, gender, household situation, average grade, and whether seeking a job). For the interaction variables, we report the effects for high scorers (four indicates agreement, and five strong agreement) and for low scorers (one indicates strong disagreement, and two disagreement). The base category is set to a value of three. The numbers represent the estimated coefficients of the main model. Mind that positive or negative effects can be based on either high or low personality trait scorers. The main effects are only reported in one direction, since they differ slightly per model. $* * * p<0.01, * * p<0.05, * p<0.1$ 
Appendix 7: All the variables in Tables 5.1 and 5.2

Variable

Economic Viability (t1)

Effect

Economic Viability (t0)

$0.111^{* *}$

(0.050)

$-0.620 * * *$

(0.211)

Physical Green Space (t1)

$-0.065$

(0.052)

Physical Green Space (t0)

$-0.176$

(0.166)

Political Populism (t1)

0.068

(0.085)

Political Populism (t0)

$-0.012$

(0.271)

Religiosity (t1)

$0.190 * * *$

(0.065)

Religiosity (t0)

$-0.211$

(0.162)

0.011

Low Agree.

(0.008)

0.000

High Agree.

(0.005)

Low Consc.

$-0.012$

(0.011)

High Consc.

0.009

(0.006)

Low Extra

$-0.018$

(0.019)

High Extra

$-0.003$

(0.007)

Low Neuro.

0.001

(0.005)

High Neuro.

0.000

(0.005)

Low Openn.

0.002

(0.015)

High Openn.

$-0.008$

(0.007)

$-0.004$

Age

(0.003)

0.000

(0.000)

$-0.004$

(0.005)

Household Situation (Base: One-person household)

Two-person household

$0.040 * * *$

(0.006)

$0.039 * * *$

Living with parent(s) 


\begin{tabular}{|c|c|}
\hline Variable & Effect \\
\hline \multirow[t]{2}{*}{ Different household } & $-0.045^{* *}$ \\
\hline & $(0.020)$ \\
\hline \multirow[t]{2}{*}{ Not looking for job (Base: Looking for job) } & 0.001 \\
\hline & $(0.006)$ \\
\hline \multirow[t]{2}{*}{ Avg. Grade } & -0.003 \\
\hline & $(0.004)$ \\
\hline \multirow[t]{2}{*}{ Economic Viability $(\mathrm{t} 1)^{*}$ Age } & -0.001 \\
\hline & $(0.002)$ \\
\hline \multirow[t]{2}{*}{ Economic Viability (t1) * Age sq. } & 0.000 \\
\hline & $(0.000)$ \\
\hline \multirow[t]{2}{*}{ Female * Economic Viability (t1) } & -0.006 \\
\hline & $(0.004)$ \\
\hline \multirow[t]{2}{*}{ Two-person household * Economic Viability (t1) } & $-0.033 * * *$ \\
\hline & $(0.004)$ \\
\hline \multirow[t]{2}{*}{ Living with parent(s) * Economic Viability (t1) } & $-0.046 * * *$ \\
\hline & $(0.012)$ \\
\hline \multirow[t]{2}{*}{ Different household * Economic Viability (t1) } & 0.011 \\
\hline & $(0.011)$ \\
\hline \multirow[t]{2}{*}{ Not looking for job * Economic Viability (t1) } & -0.006 \\
\hline & $(0.005)$ \\
\hline \multirow[t]{2}{*}{ Economic Viability (t1) * Avg. Grade } & $0.006^{*}$ \\
\hline & $(0.003)$ \\
\hline \multirow[t]{2}{*}{ Economic Viability $(\mathrm{t} 0) *$ Age } & $0.019 * *$ \\
\hline & $(0.010)$ \\
\hline \multirow[t]{2}{*}{ Economic Viability (t0) * Age sq. } & $-0.000 * *$ \\
\hline & $(0.000)$ \\
\hline \multirow[t]{2}{*}{ Female * Economic Viability (t0) } & -0.003 \\
\hline & $(0.018)$ \\
\hline \multirow[t]{2}{*}{ Two-person household * Economic Viability (t0) } & $0.069 * * *$ \\
\hline & $(0.020)$ \\
\hline \multirow[t]{2}{*}{ Living with parent(s) * Economic Viability (t0) } & $0.093^{* *}$ \\
\hline & $(0.045)$ \\
\hline \multirow[t]{2}{*}{ Different household * Economic Viability (t0) } & -0.055 \\
\hline & $(0.078)$ \\
\hline \multirow[t]{2}{*}{ Not looking for job * Economic Viability (t0) } & 0.009 \\
\hline & $(0.020)$ \\
\hline \multirow[t]{2}{*}{ Economic Viability (t0) * Avg. Grade } & -0.000 \\
\hline & $(0.014)$ \\
\hline \multirow[t]{2}{*}{ Physical Green Space (t1) * Age } & 0.002 \\
\hline & $(0.002)$ \\
\hline \multirow[t]{2}{*}{ Physical Green Space (t1) * Age sq. } & -0.000 \\
\hline & $(0.000)$ \\
\hline \multirow[t]{2}{*}{ Female * Physical Green Space (t1) } & 0.004 \\
\hline & $(0.004)$ \\
\hline Two-person household * Physical Green Space (t1) & 0.001 \\
\hline & $(0.004)$ \\
\hline Living with parent(s) * Physical Green Space (t1) & -0.002 \\
\hline & $(0.009)$ \\
\hline Different household * Physical Green Space (t1) & $-0.010 * *$ \\
\hline & $(0.004)$ \\
\hline Not looking for job * Physical Green Space (t1) & -0.007 \\
\hline & $(0.005)$ \\
\hline
\end{tabular}




\begin{tabular}{|c|c|}
\hline Variable & Effect \\
\hline \multirow[t]{2}{*}{ Physical Green Space (t1) * Avg. Grade } & 0.004 \\
\hline & $(0.003)$ \\
\hline \multirow[t]{2}{*}{ Physical Green Space (t0) * Age } & 0.005 \\
\hline & $(0.007)$ \\
\hline \multirow[t]{2}{*}{ Physical Green Space (t0) * Age sq. } & -0.000 \\
\hline & $(0.000)$ \\
\hline \multirow[t]{2}{*}{ Female * Physical Green Space (t0) } & 0.005 \\
\hline & $(0.014)$ \\
\hline \multirow[t]{2}{*}{ Two-person household * Physical Green Space (t0) } & 0.015 \\
\hline & $(0.015)$ \\
\hline \multirow[t]{2}{*}{ Living with parent(s) * Physical Green Space (t0) } & -0.017 \\
\hline & $(0.037)$ \\
\hline \multirow[t]{2}{*}{ Different household * Physical Green Space (t0) } & 0.024 \\
\hline & $(0.051)$ \\
\hline \multirow[t]{2}{*}{ Not looking for job * Physical Green Space (t0) } & 0.004 \\
\hline & $(0.016)$ \\
\hline \multirow[t]{2}{*}{ Physical Green Space (t0) * Avg. Grade } & 0.007 \\
\hline & $(0.010)$ \\
\hline \multirow[t]{2}{*}{ Political Populism (t1) * Age } & -0.001 \\
\hline & $(0.004)$ \\
\hline \multirow[t]{2}{*}{ Political Populism (t1) * Age sq. } & 0.000 \\
\hline & $(0.000)$ \\
\hline \multirow[t]{2}{*}{ Female * Political Populism (t1) } & $-0.019 * * *$ \\
\hline & $(0.007)$ \\
\hline \multirow[t]{2}{*}{ Two-person household * Political Populism (t1) } & $-0.014^{*}$ \\
\hline & $(0.008)$ \\
\hline \multirow[t]{2}{*}{ Living with parent(s) * Political Populism (t1) } & 0.026 \\
\hline & $(0.018)$ \\
\hline \multirow[t]{2}{*}{ Different household * Political Populism (t1) } & -0.008 \\
\hline & $(0.023)$ \\
\hline \multirow[t]{2}{*}{ Not looking for job * Political Populism (t1) } & 0.008 \\
\hline & $(0.008)$ \\
\hline \multirow[t]{2}{*}{ Political Populism (t1) * Avg. Grade } & -0.003 \\
\hline & $(0.005)$ \\
\hline \multirow[t]{2}{*}{ Political Populism (t0) * Age } & 0.007 \\
\hline & $(0.012)$ \\
\hline \multirow[t]{2}{*}{ Political Populism (t0) * Age sq. } & -0.000 \\
\hline & $(0.000)$ \\
\hline \multirow[t]{2}{*}{ Female * Political Populism (t0) } & 0.017 \\
\hline & $(0.022)$ \\
\hline \multirow[t]{2}{*}{ Two-person household * Political Populism (t0) } & 0.018 \\
\hline & $(0.025)$ \\
\hline \multirow[t]{2}{*}{ Living with parent(s) * Political Populism (t0) } & $-0.100^{*}$ \\
\hline & $(0.058)$ \\
\hline Different household * Political Populism (t0) & -0.040 \\
\hline & $(0.083)$ \\
\hline Not looking for job * Political Populism (t0) & -0.019 \\
\hline & $(0.026)$ \\
\hline Political Populism (t0) * Avg. Grade & -0.018 \\
\hline & $(0.018)$ \\
\hline Religiosity (t1) * Age & $-0.009 * * *$ \\
\hline & $(0.003)$ \\
\hline
\end{tabular}




\begin{tabular}{|c|c|}
\hline Variable & Effect \\
\hline \multirow[t]{2}{*}{ Religiosity (t1) * Age sq. } & $0.000 * * *$ \\
\hline & $(0.000)$ \\
\hline \multirow[t]{2}{*}{ Female * Religiosity (t1) } & -0.008 \\
\hline & $(0.005)$ \\
\hline \multirow[t]{2}{*}{ Two-person household * Religiosity (t1) } & 0.003 \\
\hline & $(0.006)$ \\
\hline \multirow[t]{2}{*}{ Living with parent(s) * Religiosity (t1) } & 0.008 \\
\hline & $(0.013)$ \\
\hline \multirow[t]{2}{*}{ Different household * Religiosity (t1) } & $-0.020^{*}$ \\
\hline & $(0.012)$ \\
\hline \multirow[t]{2}{*}{ Not looking for job * Religiosity (t1) } & 0.007 \\
\hline & $(0.006)$ \\
\hline \multirow[t]{2}{*}{ Religiosity (t1) * Avg. Grade } & 0.002 \\
\hline & $(0.004)$ \\
\hline \multirow[t]{2}{*}{ Religiosity (t0) * Age } & 0.006 \\
\hline & $(0.007)$ \\
\hline \multirow[t]{2}{*}{ Religiosity (t0) * Age sq. } & -0.000 \\
\hline & $(0.000)$ \\
\hline \multirow[t]{2}{*}{ Female * Religiosity (t0) } & -0.014 \\
\hline & $(0.013)$ \\
\hline \multirow[t]{2}{*}{ Two-person household * Religiosity (t1) 1 } & -0.009 \\
\hline & $(0.015)$ \\
\hline \multirow[t]{2}{*}{ Living with parent $(\mathrm{s}) *$ Religiosity $(\mathrm{t} 1)^{\sim} 1$} & -0.047 \\
\hline & $(0.033)$ \\
\hline \multirow[t]{2}{*}{ Different household ${ }^{*}$ Religiosity (t1) 1 } & 0.058 \\
\hline & $(0.048)$ \\
\hline \multirow[t]{2}{*}{ Not looking for job * Religiosity $(\mathrm{t} 1)^{\sim 1}$} & $0.040 * *$ \\
\hline & $(0.015)$ \\
\hline \multirow[t]{2}{*}{ Religiosity (t0) * Avg. Grade } & 0.014 \\
\hline & $(0.011)$ \\
\hline \multirow[t]{2}{*}{ Low Agree. * Economic Viability (t1) } & -0.005 \\
\hline & $(0.006)$ \\
\hline \multirow[t]{2}{*}{ High Agree. ${ }^{*}$ Economic Viability (t1) } & -0.003 \\
\hline & $(0.003)$ \\
\hline \multirow[t]{2}{*}{ Low Consc. * Economic Viability (t1) } & -0.006 \\
\hline & $(0.007)$ \\
\hline \multirow[t]{2}{*}{ High Consc. ${ }^{*}$ Economic Viability (t1) } & $-0.009 * *$ \\
\hline & $(0.004)$ \\
\hline \multirow[t]{2}{*}{ Low Extra. ${ }^{*}$ Economic Viability (t1) } & 0.001 \\
\hline & $(0.011)$ \\
\hline \multirow[t]{2}{*}{ High Extra. * Economic Viability (t1) } & -0.001 \\
\hline & $(0.005)$ \\
\hline \multirow[t]{2}{*}{ Low Neuro. * Economic Viability (t1) } & -0.005 \\
\hline & $(0.004)$ \\
\hline High Neuro. * Economic Viability (t1) & -0.002 \\
\hline & $(0.005)$ \\
\hline Low Openn. * Economic Viability (t1) & -0.006 \\
\hline & $(0.011)$ \\
\hline High Openn. * Economic Viability (t1) & 0.005 \\
\hline & $(0.005)$ \\
\hline Low Agree. * Economic Viability (t0) & -0.000 \\
\hline & $(0.029)$ \\
\hline
\end{tabular}




\begin{tabular}{|c|c|}
\hline Variable & Effect \\
\hline \multirow[t]{2}{*}{ High Agree. * Economic Viability (t0) } & 0.018 \\
\hline & $(0.019)$ \\
\hline \multirow[t]{2}{*}{ Low Consc. * Economic Viability (t0) } & -0.001 \\
\hline & $(0.040)$ \\
\hline \multirow[t]{2}{*}{ High Consc. ${ }^{*}$ Economic Viability (t0) } & 0.009 \\
\hline & $(0.023)$ \\
\hline \multirow[t]{2}{*}{ Low Extra. * Economic Viability (t0) } & 0.091 \\
\hline & $(0.074)$ \\
\hline \multirow[t]{2}{*}{ High Extra. * Economic Viability (t0) } & -0.017 \\
\hline & $(0.027)$ \\
\hline \multirow[t]{2}{*}{ Low Neuro. * Economic Viability (t0) } & 0.018 \\
\hline & $(0.018)$ \\
\hline \multirow[t]{2}{*}{ High Neuro. * Economic Viability (t0) } & 0.005 \\
\hline & $(0.030)$ \\
\hline \multirow[t]{2}{*}{ Low Openn. * Economic Viability (t0) } & 0.031 \\
\hline & $(0.056)$ \\
\hline \multirow[t]{2}{*}{ High Openn. * Economic Viability (t0) } & 0.022 \\
\hline & $(0.024)$ \\
\hline \multirow[t]{2}{*}{ Low Agree. * Physical Green Space (t1) } & 0.007 \\
\hline & $(0.008)$ \\
\hline \multirow[t]{2}{*}{ High Agree. * Physical Green Space (t1) } & $0.008^{*}$ \\
\hline & $(0.004)$ \\
\hline \multirow[t]{2}{*}{ Low Consc. * Physical Green Space (t1) } & 0.007 \\
\hline & $(0.009)$ \\
\hline \multirow[t]{2}{*}{ High Consc. * Physical Green Space (t1) } & 0.003 \\
\hline & $(0.005)$ \\
\hline \multirow[t]{2}{*}{ Low Extra. * Physical Green Space (t1) } & -0.007 \\
\hline & $(0.020)$ \\
\hline \multirow[t]{2}{*}{ High Extra. * Physical Green Space (t1) } & -0.007 \\
\hline & $(0.006)$ \\
\hline \multirow[t]{2}{*}{ Low Neuro. * Physical Green Space (t1) } & 0.001 \\
\hline & $(0.005)$ \\
\hline \multirow[t]{2}{*}{ High Neuro. * Physical Green Space (t1) } & $-0.011 * *$ \\
\hline & $(0.005)$ \\
\hline \multirow[t]{2}{*}{ Low Openn. * Physical Green Space (t1) } & $-0.014^{*}$ \\
\hline & $(0.008)$ \\
\hline \multirow[t]{2}{*}{ High Openn. * Physical Green Space (t1) } & 0.001 \\
\hline & $(0.007)$ \\
\hline \multirow[t]{2}{*}{ Low Agree. * Physical Green Space (t0) } & -0.027 \\
\hline & $(0.025)$ \\
\hline \multirow[t]{2}{*}{ High Agree. * Physical Green Space (t0) } & 0.000 \\
\hline & $(0.015)$ \\
\hline \multirow[t]{2}{*}{ Low Consc. * Physical Green Space (t0) } & -0.004 \\
\hline & $(0.032)$ \\
\hline High Consc. * Physical Green Space (t0) & 0.011 \\
\hline & $(0.018)$ \\
\hline Low Extra. * Physical Green Space (t0) & 0.011 \\
\hline & $(0.055)$ \\
\hline High Extra. * Physical Green Space (t0) & -0.002 \\
\hline & $(0.020)$ \\
\hline Low Neuro. * Physical Green Space (t0) & -0.005 \\
\hline & $(0.014)$ \\
\hline
\end{tabular}




\begin{tabular}{|c|c|}
\hline Variable & Effect \\
\hline \multirow[t]{2}{*}{ High Neuro. * Physical Green Space (t0) } & 0.008 \\
\hline & $(0.021)$ \\
\hline \multirow[t]{2}{*}{ Low Openn. * Physical Green Space (t0) } & $0.067^{*}$ \\
\hline & $(0.038)$ \\
\hline \multirow[t]{2}{*}{ High Openn. * Physical Green Space (t0) } & $0.039 * *$ \\
\hline & $(0.018)$ \\
\hline \multirow[t]{2}{*}{ Low Agree. * Political Populism (t1) } & 0.008 \\
\hline & $(0.012)$ \\
\hline \multirow[t]{2}{*}{ High Agree. * Political Populism (t1) } & -0.006 \\
\hline & $(0.007)$ \\
\hline \multirow[t]{2}{*}{ Low Consc. * Political Populism (t1) } & $-0.037 * *$ \\
\hline & $(0.016)$ \\
\hline \multirow[t]{2}{*}{ High Consc. ${ }^{*}$ Political Populism (t1) } & 0.011 \\
\hline & $(0.009)$ \\
\hline \multirow[t]{2}{*}{ Low Extra. * Political Populism (t1) } & -0.005 \\
\hline & $(0.025)$ \\
\hline \multirow[t]{2}{*}{ High Extra. * Political Populism (t1) } & -0.004 \\
\hline & $(0.010)$ \\
\hline \multirow[t]{2}{*}{ Low Neuro. * Political Populism (t1) } & -0.005 \\
\hline & $(0.007)$ \\
\hline \multirow[t]{2}{*}{ High Neuro. * Political Populism (t1) } & 0.001 \\
\hline & $(0.011)$ \\
\hline \multirow[t]{2}{*}{ Low Openn. * Political Populism (t1) } & -0.031 \\
\hline & $(0.021)$ \\
\hline \multirow[t]{2}{*}{ High Openn. * Political Populism (t1) } & 0.006 \\
\hline & $(0.010)$ \\
\hline \multirow[t]{2}{*}{ Low Agree. * Political Populism (t0) } & -0.050 \\
\hline & $(0.037)$ \\
\hline \multirow[t]{2}{*}{ High Agree. ${ }^{*}$ Political Populism (t0) } & -0.024 \\
\hline & $(0.024)$ \\
\hline \multirow[t]{2}{*}{ Low Consc. * Political Populism (t0) } & 0.033 \\
\hline & $(0.054)$ \\
\hline \multirow[t]{2}{*}{ High Consc. * Political Populism (t0) } & -0.029 \\
\hline & $(0.029)$ \\
\hline \multirow[t]{2}{*}{ Low Extra. * Political Populism (t0) } & 0.050 \\
\hline & $(0.093)$ \\
\hline \multirow[t]{2}{*}{ High Extra. * Political Populism (t0) } & -0.008 \\
\hline & $(0.035)$ \\
\hline \multirow[t]{2}{*}{ Low Neuro. * Political Populism (t0) } & -0.012 \\
\hline & $(0.023)$ \\
\hline \multirow[t]{2}{*}{ High Neuro. * Political Populism (t0) } & -0.036 \\
\hline & $(0.037)$ \\
\hline \multirow[t]{2}{*}{ Low Openn. * Political Populism (t0) } & $0.135^{*}$ \\
\hline & $(0.079)$ \\
\hline High Openn. * Political Populism (t0) & 0.017 \\
\hline & $(0.030)$ \\
\hline Low Agree. * Religiosity (t1) & -0.003 \\
\hline & $(0.009)$ \\
\hline High Agree. * Religiosity (t1) & -0.007 \\
\hline & $(0.006)$ \\
\hline Low Consc. * Religiosity (t1) & $-0.020^{*}$ \\
\hline & $(0.012)$ \\
\hline
\end{tabular}




\begin{tabular}{|c|c|}
\hline Variable & Effect \\
\hline \multirow[t]{2}{*}{ High Consc. ${ }^{*}$ Religiosity (t1) } & -0.006 \\
\hline & $(0.007)$ \\
\hline \multirow[t]{2}{*}{ Low Extra. * Religiosity (t1) } & -0.002 \\
\hline & $(0.018)$ \\
\hline \multirow[t]{2}{*}{ High Extra. * Religiosity (t1) } & $-0.014^{*}$ \\
\hline & $(0.008)$ \\
\hline \multirow[t]{2}{*}{ Low Neuro. ${ }^{*}$ Religiosity (t1) } & 0.000 \\
\hline & $(0.006)$ \\
\hline \multirow[t]{2}{*}{ High Neuro. ${ }^{*}$ Religiosity (t1) } & -0.005 \\
\hline & $(0.009)$ \\
\hline \multirow[t]{2}{*}{ Low Openn. * Religiosity (t1) } & 0.007 \\
\hline & $(0.017)$ \\
\hline \multirow[t]{2}{*}{ High Openn. * Religiosity (t1) } & -0.004 \\
\hline & $(0.008)$ \\
\hline \multirow[t]{2}{*}{ Low Agree. * Religiosity (t0) } & -0.006 \\
\hline & $(0.023)$ \\
\hline \multirow[t]{2}{*}{ High Agree. * Religiosity (t0) } & 0.004 \\
\hline & $(0.014)$ \\
\hline \multirow[t]{2}{*}{ Low Consc. * Religiosity (t0) } & -0.018 \\
\hline & $(0.030)$ \\
\hline \multirow[t]{2}{*}{ High Consc. * Religiosity (t0) } & -0.009 \\
\hline & $(0.018)$ \\
\hline \multirow[t]{2}{*}{ Low Extra. * Religiosity (t0) } & -0.026 \\
\hline & $(0.054)$ \\
\hline \multirow[t]{2}{*}{ High Extra. ${ }^{*}$ Religiosity (t0) } & -0.007 \\
\hline & $(0.021)$ \\
\hline \multirow[t]{2}{*}{ Low Neuro. * Religiosity (t0) } & $-0.029 * *$ \\
\hline & $(0.014)$ \\
\hline \multirow[t]{2}{*}{ High Neuro. ${ }^{*}$ Religiosity (t0) } & -0.008 \\
\hline & $(0.021)$ \\
\hline \multirow[t]{2}{*}{ Low Openn. * Religiosity (t0) } & -0.018 \\
\hline & $(0.046)$ \\
\hline \multirow[t]{2}{*}{ High Openn. * Religiosity (t0) } & 0.011 \\
\hline & $(0.017)$ \\
\hline \multirow[t]{2}{*}{ Prior mobility (dummy) } & 0.002 \\
\hline & $(0.004)$ \\
\hline \multirow[t]{2}{*}{ Distance to move } & $-0.002 * * *$ \\
\hline & $(0.000)$ \\
\hline \multirow[t]{2}{*}{ Distance to move ${ }^{2}$} & $0.000 * * *$ \\
\hline & $(0.000)$ \\
\hline \multirow[t]{2}{*}{ Constant } & $0.826 * * *$ \\
\hline & (0.059) \\
\hline
\end{tabular}

Note: For the interaction variables, we report the effects for high scorers (four indicates agreement, and five strong agreement) and for low scorers (one indicates strong disagreement, and two disagreement). The base category is set to a value of three.

$* * * p<0.01, * * p<0.05, * p<0.1$ 